\title{
Evolution of the Austral-Antarctic flora during the Cretaceous: New insights from a paleobiogeographic perspective
}

\author{
Evolución de la flora austral-antártica durante el Cretácico: Una nueva mirada desde una \\ perspectiva paleobiogeográfica
}

\author{
MARCELO LEPPE ${ }^{1}$, MARITZA MIHOC ${ }^{2}$, NATALIA VARELA ${ }^{3}$, WOLFGANG STINNESBECK ${ }^{4}$, HÉCTOR MANSILLA ${ }^{5}$, \\ HESSEL BIERMA $^{3}$, KATHERINE CISTERNA ${ }^{2}$, EBERHARD FREY ${ }^{6} \&$ TOSHIRO JUJIHARA $^{5}$ \\ ${ }^{1}$ Laboratorio de Paleobiología, Instituto Antártico Chileno, Plaza Muñoz Gamero 1055, Punta Arenas, Chile \\ 2Departamento de Botánica, Universidad de Concepción, Casilla 160-C, Concepción, Chile \\ ${ }^{3}$ Departamento Ciencias de La Tierra, Universidad de Concepción, Casilla 160-C, Concepción, Chile \\ ${ }^{4}$ Institut für Geowissenschaften, Ruprecht-Karls-Universität Heidelberg, Im Neuenheimer Feld 234-236, 69120 Heidelberg, Germany \\ ${ }^{5}$ Universidad de Magallanes, Av. Bulnes 01855, Casilla 113D, Punta Arenas, Chile \\ ${ }^{6}$ Staatliches Museum für Naturkunde Karlsruhe (SMNK), Erbprinzenstraße 13, 76133 Karlsruhe, Germany \\ *Corresponding author: mleppe@inach.cl
}

\begin{abstract}
Forest environments have continuously existed in Antarctica since the late Paleozoic and only disappeared from this continent since the Neogene. Nevertheless, the structure of these forests underwent substantial evolutionary changes. During the late Cretaceous, forests dominated by conifers and pteridophytes were gradually replaced by angiospermdominated forests. Elements common to these Antarctic forests are important constituents of the recent Valdivian Forest. During the Turonian stage of the Late Cretaceous, the Antarctic Peninsula and Patagonia were reconnected by a land bridge after a separation since the end of the Jurassic. Using biogeographic tools applied to the palynological and leaf imprint record, outcrops of Campanian-Maastrichtian age were studied from the Snow Hill, James Ross and Seymour (Marambio) Islands in the James Ross basin, Antarctica; Skua Bay, Half Three Point, Price Point and Zamek Hill on King George Island, Antarctica, and Rocallosa Point, Cerro Guido, Las Chinas, Dorotea Hill, Cazador Hill and La Irene in Chilean-Argentinian Patagonia, comparing the current distribution and the paleogeography, as well as the influence of potential areas of endemism and vicariants events. The analysis indicates that vegetation evolved under environmental conditions subject to intense volcanic and climatic disturbances, with changes from a period with extreme greenhouse climate (Turonian-Campanian) to strong cooling during the Maastrichtian. We suggest that a continuous forest existed in southern South America and Antarctica, which was shaped during the Latest Cretaceous by the presence of marine basins and and intermittent connection and disconnection of the flora.
\end{abstract}

Key words: Antarctica, Cretaceous, Magellan's basin, paleobotany, Patagonia.

\section{RESUMEN}

Se sabe que al menos desde fines del Paleozoico ambientes boscosos habrían existido en la Antártica y habrían desaparecido de ella solo a fines del Terciario. Sin embargo, la estructura no ha sido la misma, evolucionando desde un bosque dominado por coníferas y pteridófitas durante el Cretácico Inferior, a bosques dominados por angiospermas a partir del Cretácico Superior, con elementos comunes a los constituyentes actuales de la Selva Valdiviana. Durante el Turoniano la Península Antártica y Patagonia se reunieron por un puente terrestre rompiendo millones de años de desconexión, y gracias a una variedad de ambientes de sedimentación, se han conservado numerosos vestigios de la flora que cubrió ambos subcontientes. Mediante herramientas biogeográficas aplicadas al registro palinológico y de improntas foliares, afloramientos campaniano-maastrichtianos de islas Snow Hill, James Ross y Seymour (Marambio), en la cuenca de James Ross, Antártica; bahía Skúa, punta Half Three, punta Price y cerro Zamek, en la isla Rey Jorge, Antártica; y punta Rocallosa, cerro Guido, Las Chinas, cerro Dorotea, cerro Cazador y La Irene en la Patagonia chileno-argentina, se estudió la relación entre la distribución actual y la paleogeografía, considerandolos potenciales eventos vicariantes y áreas de endemismo establecidas. Reconstrucciones paleoecológicas muestran que los elencos vegetacionales habrían evolucionado en el marco de ambientes sometidos a intensa perturbación volcánica y climáticamente habrían estado sometidos a uno de los lapsos más cálidos de la historia natural, pero con fuertes pulsos de enfriamiento durante el Campaniano y Maastrichtiano. Se sostiene que entre el Maastrichtiano y el Eoceno, existió un continuo forestal entre Patagonia y Sudamérica que habría sido modelado por la presencia de las cuencas marinas finicretácicas y la intermitente conexión-desconexión de las floras.

Palabras clave: Antártica, Cretácico, cuenca de Magallanes, paleobotánica, Patagonia. 


\section{INTRODUCTION}

Forest ecosystems have existed in Antarctica since the Late Paleozoic (Axelrod 1984, Hunt \& Poole 2003, Taylor et al. 1992) evolving mainly in conditions warmer than the present, until the Neogene (Cantrill 2001, Francis \& Poole 2002), when a sharp drop in temperature occurred at the Oligo-Miocene boundary. The structure of vegetation, however, underwent considerable changes, from forests dominated by conifers and pteridophytes during the Early Cretaceous (Falcon-Lang et al. 2001) to forests dominated by angiosperms, similar to Valdivian forests of southern Chile. These last conditions gradually established during the Late Cretaceous, after the massive radiation of angiosperms throughout Gondwana. Common elements of these Upper Cretaceous floras of Antarctica are now well represented in different types of modern Chilean forests (Dutra \& Batten 2000, Poole et al. 2001, Cantrill \& Poole 2002, Leppe et al. 2007). Deposits of Late Cretaceous and Paleogene age are well recorded from the James Ross Basin and the Fildes Peninsula Group, King George Island, as well as from the Magallanes basin in southern Patagonia (Cantrill 1997, 2000, Torres et al. 1997, Césari et al. 1999). Paleoecological reconstructions indicate that floristic casts have evolved in the context of environments under intense volcanic disturbance (Poole et al. 2001). Climatically, the Late Cretaceous was one of the warmest periods of the Phanerozoic, with warm pulses during the Turonian and cold events during the Maastrichtian (Huber 1998). Low temperatures near to the end of the Cretaceous were again followed by an increase in temperature, or climatic optimum, during the Paleocene and Eocene (Upchurch et al. 1998).

A terrestrial connection during the Campanian-Maastrichtian between South America and Antarctica is crucial to understand the establishment of a new structure in the austral vegetation. Upper Jurassic-Lower Cretaceous taxa evolved isolated in both Antarctic and Patagonian communities until the reestablishment of a terrestrial bridge between both landmasses during the Turonian (Pankhurst \& Smellie 1983, Smellie et al. 1984). During the Campanian-Maastrichtian this connection led to a new mixed AntarcticPatagonian biota predecessor of modern southern South American temperate forests. Recently, new arguments have extended the discussion about the origins and persistence of these southern temperate biota, particularly of the Valdivian forest, a broadleaf and mixed forest ecoregion on the west coast of southern South America, mostly in Chile and western Argentina (Poole et al 2003, Povilauskas et al. 2008). Several authors have pointed out that the Valdivian forest is the closest equivalent to Upper Cretaceous-Paleogene forests from Antarctica (Axelrod 1984, Francis \& Poole 2002, Cantrill 2001, Poole et al. 2003), but this hypothesis was based only on a few taxa or localities. During the past 10 years, however, enormous volumes of multidisciplinary data were published on paleomagnetism, sedimentary provenance, paleobiogeography, molecular phylogeny and paleoecology, among many other disciplines. These datasets offer alternative or complimentary explanations to the complex relationship between the geological and biological evolution of the Antarctic-Patagonian region, from which integrated studies have been scarce.

\section{Geological setting}

Movements of two major plates of the former Gondwana continent, South America and Antarctica, control the modern tectonic scenario in the region. These are in turn linked to four minor plates: Scotia, Drake, South Sandwich and South Shetland (Augusto et al. 2007). The Late Cretaceous was the time when the final breakup of Gondwana occurred and led to the isolation of Antarctica. Paleontological data indicate that the Antarctic Peninsula was adjacent to southern South America during almost all of the Mesozoic, allowing for an active migration and exchange of terrestrial faunal and floral assemblages. This interchange between South America and the Antarctic Peninsula ceased during the Paleogene when a shallow seaway developed, but the final continent separation did not occur until the early Neogene with the development of deep sea conditions in the Drake passage (Zinsmeister 1987).

The Austral Basin is located in southern South Patagonia and is composed of three sub-basins (Suarez et al. 2009). The Rocas Verdes Basin was active during the Late 
Jurassic and Early Cretaceous and was formed by an extensional tectonic regime associated with the separation of southern Gondwana (Dalziel \& Cortés 1972, Suarez 1979, Dalziel 1981). The closure of the Rocas Verdes Basin during the mid-Cretaceous was accompanied by the collision of the Cape Horn Microplate with South America (Dalziel 1981). This is the moment when deposition started in the Magallanes Basin (Suarez et al. 2009). The Magallanes Basin was initially filled with turbiditic siliciclastic sediment (Natland et al. 1974, Fildani et al. 2007, Pardo et al. 2012), with the protoAndes as the main source of sediment infill (Fildani et al. 2007). The Upper Cretaceous sediment sequence of the Magellanes basin the Última Esperanza Province reflects gradual shallowing towards slope and subsequently to shallow marine environments prograding to the south. Deltaic environments first occured in the Lago Argentino area. An example of the massive retrogradational marine deposits in the Magallanes Basin is exposed in the Tres Pasos Formation, Última Esperanza Province, equivalent to Rosa and Fuentes Formations in the Seno Skyring and Brunswick Peninsula area (Fig. 1). In this region deep marine environments were gradually replaced by shallow marine and finally alluvial fan deposits known as Dorotea Formation, in Chile, or Cerro Cazador Formation in Argentina (Macellari et al. 1989, Malumián \& Caramés 1997). These formations were assigned to the Upper Campanian-Maastrichtian based on ammonite occurrences (Macellari 1988, Macellari et al. 1989, Malumián \& Caramés 1997). The top of the sediment sequence is still known as Cerro Dorotea Formation in Chile, while coeval sediments on the Argentinian side adjacent to the northern border of the Última Esperanza Province are known as the La Irene Formation. This latter unit corresponds to sandstone and conglomerate deposited in a meandering river environment. The Calafate Formation unconformably overlies the La Irene Formation (Macellari et al. 1989) and is now also considered to be Maastrichtian in age (Marenssi et al. 2004). This unit represents alluvial to estuarine deposits and is equivalent to the top of the sediment sequence known from Cerro Guido and Las Chinas in the Última Esperanza Province.

The Antarctic Peninsula allocates the remnants of a continental margin to the southeast and of a magmatic arc of MesoCenozoic age to the northwest, the latter resulting from the subduction of oceanic plate

\begin{tabular}{|c|c|c|c|c|c|c|c|c|c|c|}
\hline \multirow[b]{3}{*}{ Age } & \multicolumn{5}{|c|}{ MAGALLANES BASIN, PATAGONIA } & \multicolumn{5}{|c|}{ ANTARCTIC PENINSULA } \\
\hline & \multicolumn{2}{|c|}{ Argentina } & \multicolumn{3}{|c|}{ Chile } & \multicolumn{2}{|c|}{ King George Island } & \multirow[b]{2}{*}{$\begin{array}{l}\text { James Ross } \\
\text { Island }\end{array}$} & \multirow[b]{2}{*}{ Seymour Island } & \multirow[b]{2}{*}{$\begin{array}{l}\text { Snow Hill } \\
\text { Island }\end{array}$} \\
\hline & $\begin{array}{c}\text { Lago } \\
\text { Argentino }\end{array}$ & $\begin{array}{r}\text { Ulti } \\
\text { Esper }\end{array}$ & ima & Skyring Bay & $\begin{array}{c}\text { Strait } \\
\text { of } \\
\text { Magellan }\end{array}$ & Fildes Peninsula & Admiralty Bay & & & \\
\hline \multirow{3}{*}{ Maastrichtian } & Calafate Fm. & \begin{tabular}{|c|}
$\begin{array}{c}\text { Cerro Dorotcal } \\
\mathrm{Fm} .\end{array}$ \\
\end{tabular} & & & Río Blanco Fm. & Jasper Hill & \multirow[b]{2}{*}{ Zamek Fm. } & \multirow{2}{*}{$\begin{array}{c}\text { Lopez de } \\
\text { Bertodano } \\
\text { Fm. }\end{array}$} & \multirow{2}{*}{$\begin{array}{l}\text { Lopez de } \\
\text { Bertodano } \mathrm{Fm} .\end{array}$} & \multirow{2}{*}{$\begin{array}{l}\text { Lopez de } \\
\text { Bertodano } \mathrm{Fm} .\end{array}$} \\
\hline & Chorrillo Fm. & Cerro & Dorotea & \multirow{2}{*}{ Rocallosa $\mathrm{Fm}$. } & \multirow[b]{2}{*}{ Santa Ana Fm. } & \multirow{3}{*}{$\begin{array}{c}\text { Half Three Point } \\
\text { Fm. }\end{array}$} & & & & \\
\hline & 工 $_{\text {Cerro Fortaleza }}^{\text {La Irene Fmi }}$ & $\begin{array}{l}\text { Cazador } \\
\mathrm{Fm}\end{array}$ & $\mathrm{Fm}$. & & & & \multirow[b]{2}{*}{ Llano Point Fm. } & \multirow{2}{*}{$\begin{array}{l}\text { Snow Hill } \\
\text { Island } \mathrm{Fm} \text {. }\end{array}$} & \multirow{2}{*}{$\begin{array}{l}\text { Snow Hill } \\
\text { Island Fm. }\end{array}$} & \multirow{2}{*}{$\begin{array}{l}\text { Snow Hill } \\
\text { Island Fm. }\end{array}$} \\
\hline \multirow{2}{*}{ Campanian } & $\frac{\mathrm{Fm} .}{\text { La Anita Fm. }}$ & \multirow{2}{*}{\multicolumn{2}{|c|}{ Tres Pasos Fm. }} & $\begin{array}{l}\text { Fuentes } \\
\text { Fm. }\end{array}$ & $\begin{array}{c}\text { San Isidro } \mathrm{Fm} . \\
\text { Fuentes } \mathrm{Fm} \text {. }\end{array}$ & & & & & \\
\hline & Alta Vista Fm. & & & Rosa Fm. & Rosa Fm. & & & \multirow[b]{2}{*}{$\begin{array}{c}\text { Santa Marta } \\
\text { Fm. }\end{array}$} & \multirow{3}{*}{$\begin{array}{c}\text { Santa Marta } \\
\text { Fm. } \\
\text { ??? }\end{array}$} & \multirow{3}{*}{$? ? ?$} \\
\hline 83,5 m.a & & \multirow{2}{*}{\multicolumn{2}{|c|}{ Cerro Toro Fm. }} & & & & & & & \\
\hline $\begin{array}{r}\text { Santonian } \\
85,8 \mathrm{~m} . \mathrm{a}\end{array}$ & Cerro Toro Fm. & & & Barcarcel Fm. & Barcarcel Fm. & & & $\begin{array}{l}\text { Hidden } \\
\text { Lake Fm. }\end{array}$ & & \\
\hline
\end{tabular}

\begin{tabular}{|c|c|c|c|c|c|c|}
\hline References & $\begin{array}{l}\text { MACELLARI,1988, } \\
\text { MACERALLI et al } 1989, \\
\text { MALUMIAN et al } 1996\end{array}$ & MACELLARI, 1988 & $\begin{array}{c}\text { BIRKENMAJER \& ZASTAWNIAK } 1989 \\
\text { BIRKENMAJER, } 2001\end{array}$ & HATHWAY, 2000 & $\begin{array}{c}\text { ELLIOT 1998, } \\
\text { CRAME et al, 199, } \\
\text { RIDING } \& \\
\text { CRAME } 2002\end{array}$ & PIRRIE et al, 1996 \\
\hline
\end{tabular}

Fig. 1: Correlation of the main Upper Cretaceous Formations of the Magallanes Basin, considering both Argentinian and Chilean nomenclature, and James Ross Basin and King George Island of the Antarctic Peninsula. Macellari 1988, Macellari et al. 1989, Malumián et al. 1997, Birkenmajer \& Zastawniak 1989, Birkenmajer 2001, Hathway 2000, Elliot 1988, Crame et al. 1991, Riding \& Crame 2002 and Pirrie et al. 1997.

Correlación de las principales formaciones del Cretácico superior de la Cuenca de Magallanes (considerando la nomenclatura chilena y argentina) y la Península Antártica (considerando la cuenca de James Ross y la isla Rey Jorge). Macellari 1988, Macellari et al. 1989, Malumián et al. 1997, Birkenmajer \& Zastawniak 1989, Birkenmajer 2001, Hathway 2000, Elliot 1988, Crame et al. 1991, Riding \& Crame 2002 and Pirrie et al. 1997. 


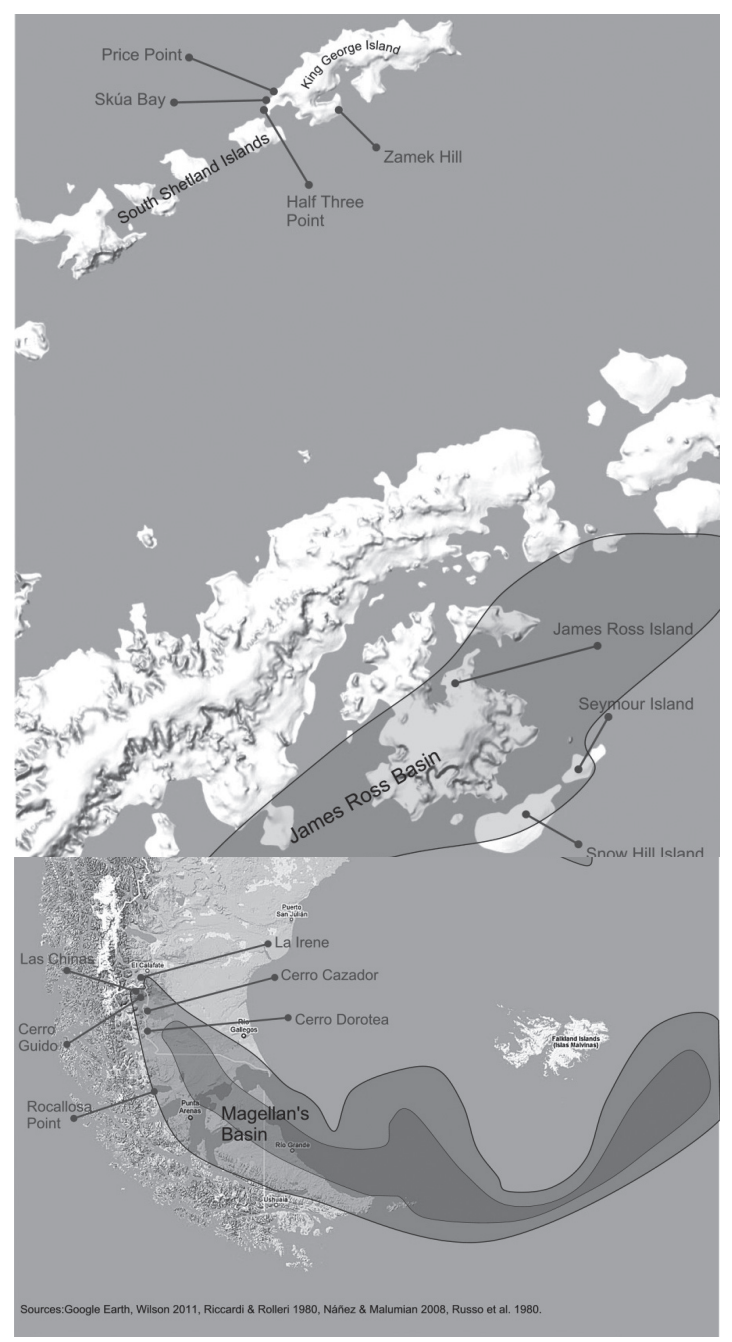

Fig. 2: Geographical location of sections studied here. Top: Antarctic localities; Below: Patagonian localities. Riccardi \& Rolleri 1980, Russo et al. 1980, Náñez \& Malumian 2008.

La posición geográfica de las localidades estudiadas. Arriba: localidades antárticas; Abajo: localidades patagónicas. Riccardi \& Rolleri 1980, Russo et al. 1980, Náñez \& Malumian 20082011.

beneath the Paleopacific margin (Fig. 2). The magmatic arc, as well as accretional complexes reflecting forearc and back-arc conditions, preserves a variety of paleoenvironments, many of which contain fossil plants (Poole \& Cantrill 2006). Plant-bearing units include the Half Three Point Formation (Shen 1994) of Late Campanian or Campanian-Maastrichtian age (Cao 1992), a lacustrine deposit reflecting a subtropical humid climatic interval (Shen 1994). Campanian-Maastrichtian plants are also known from Price Point, presenting a dominance of angiosperms, and from Skua Bay where the megaflora, though poorly preserved, is dominated by ferns. The Skua Bay flora may be slightly younger than assemblages identified in other Upper Cretaceous localities on King George Island, and they are markedly different to assemblages of the Zamek Hill Formation at Admiralty Bay, which is exceedingly rich in Nothofagus (Dutra \& Batten 2000). In contrast, the James Ross Basin in the northeastern part of the Antarctic peninsula (Figs. 1-2) developed in a back-arc location in response to the south-eastward-directed subduction of proto-Pacific oceanic lithosphere beneath the Antarctic Peninsula magmatic arc (Pirrie et al. 1997). The basin fill constitutes a regressive megasequence (Nelson 1975, Ineson et al. 1986, Crame et al. 1991). For instance, the Aptian-Turonian of the basin is characterized by submarine fan deposits, whereas the Snow Hill Island Formation of late Campanian-early Maastrichtian age reflects a shallow shelf environment based on mollusc assemblages including the ammonite Gunnarites antarcticus. The Snow Hill Island Formation unconformably underlies the Maastrichtian López de

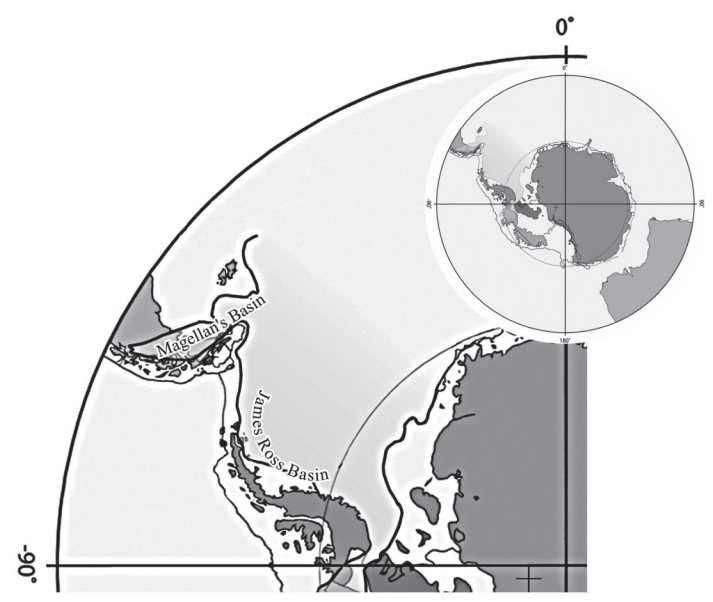

Fig. 3: Reconstruction of Austral basins of South America and the Antarctic Peninsula modified from Lawver et al. (2009). The continental connection during the Campanian and Maastrichtian is shown as an isthmus between the Antarctic Peninsula and Patagonia.

Reconstrucción de la Cuenca Austral modificada de Lawver et al. (2009). La conexión durante el Campaniano y Maastrichtiano se muestra como un istmo entre la península Antártica y Patagonia. 


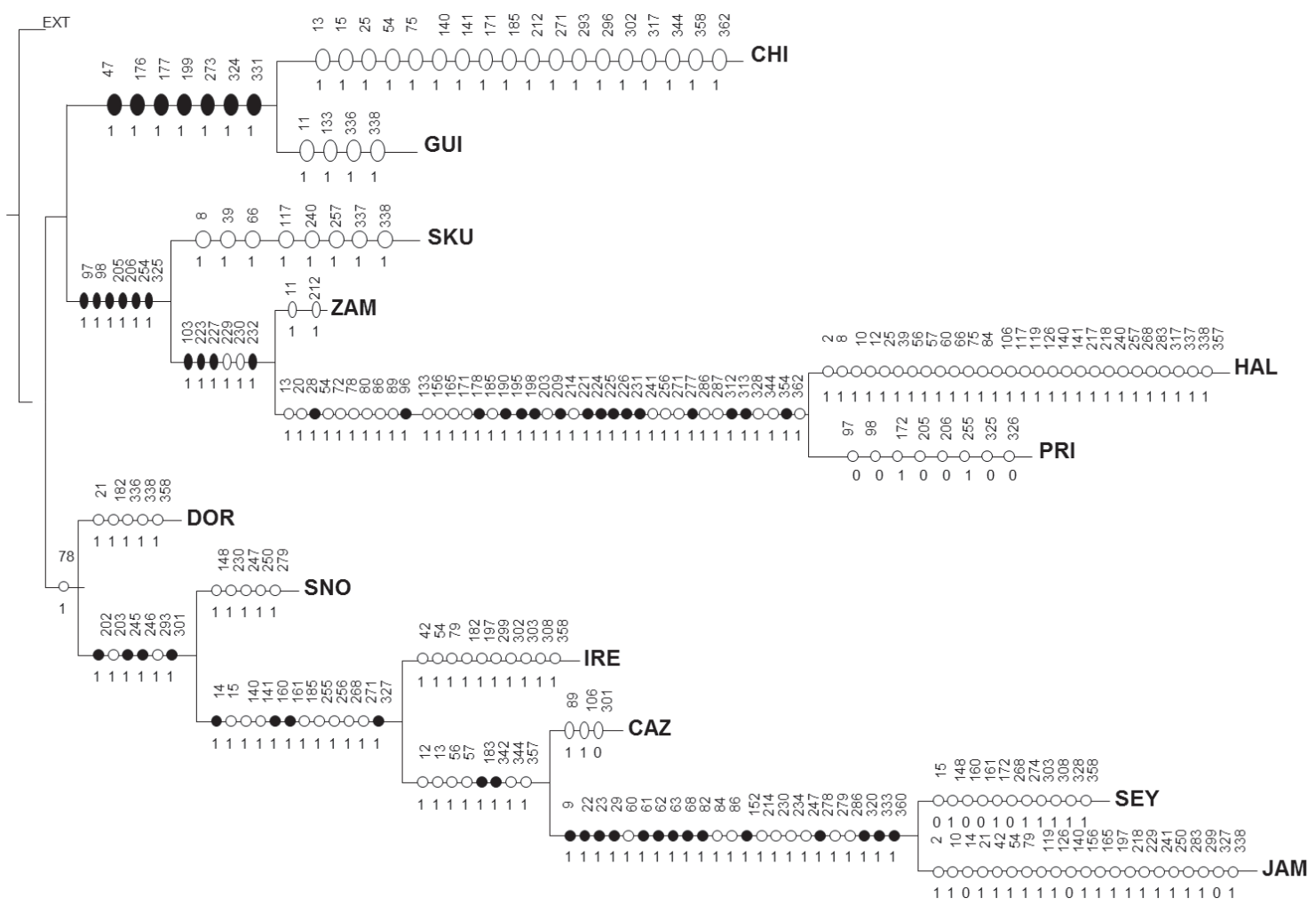

Fig. 4: Most parsimonious tree generated by PAE of taxa from Patagonia and the Antarctic Peninsula during the Campanian-Maastrichtian. (L: 292, CI: 51, RI: 54). Black dots represent synapomorphy and white dots homoplasy.

Árbol más parsimonioso generado por el PAE para taxa de Patagonia y la Península Antártica durante el lapso Campaniano Maastrichtiano. (L: 292, CI: 51, RI: 54). Puntos negros representan sinapomorfías y los blancos homoplasia.

Bertodano Formation, which is restricted to the northern tip of Snow Hill Island, to Seymour Island, and to a small exposure on Vega Island (Pirrie et al. 1997). This sequence thus represents one of the most complete Upper Cretaceous sections in the Southern hemisphere, with a wide record of paleoenvironments and diverse biota.

Here we suggest that biogeographic bridges connected Patagonia and the Antarctic Peninsula during the last interval of the Late Cretaceous (Fig. 2), generating one or more ancestral biota. The geographic continuity of Patagonia and the Antarctic Peninsula, currently disjointed by the Drake Passage, may partly explain the vicariant pattern and areas of endemism, but weather patterns differing between the western and eastern side of the isthmus may also have played in important role.

\section{METHODS}

The biogeographic analysis presented here is based on fossil plant associations from Antarctic localities at Snow Hill Island, James Ross Island, Seymour (Marambio) Island, Skua Bay (King George Island), Half Three Point (King George Island), Price Point (King George Island) and Zamek Hill (King George Island), as well as from Patagonian localities at Rocallosa Point (Riesco Island), Guido Hill, Las Chinas, Dorotea Hill in Chile, and and Cazador Hill and La Irene in Argentina (Fig. 2). Las Chinas is a new locality not documented before. Six localities were studied during field campaigns from 2008 to 2011 (Las Chinas, Cerro Guido, Half Three Point, Skua Bay, Price Point and Cerro Dorotea). Distributional data of fossils and localities were obtained from the review of published articles, books and field campaigns (See Appendix). With this information at hand, a georeferenced record database was performed. A geographic distribution map of each taxon was obtained using ArcView GIS 3.2. Altogether, 4044 records were used. A total of 364 taxa were registered, 71 of which correspond to leaf imprints and 293 to palynomorphs. 


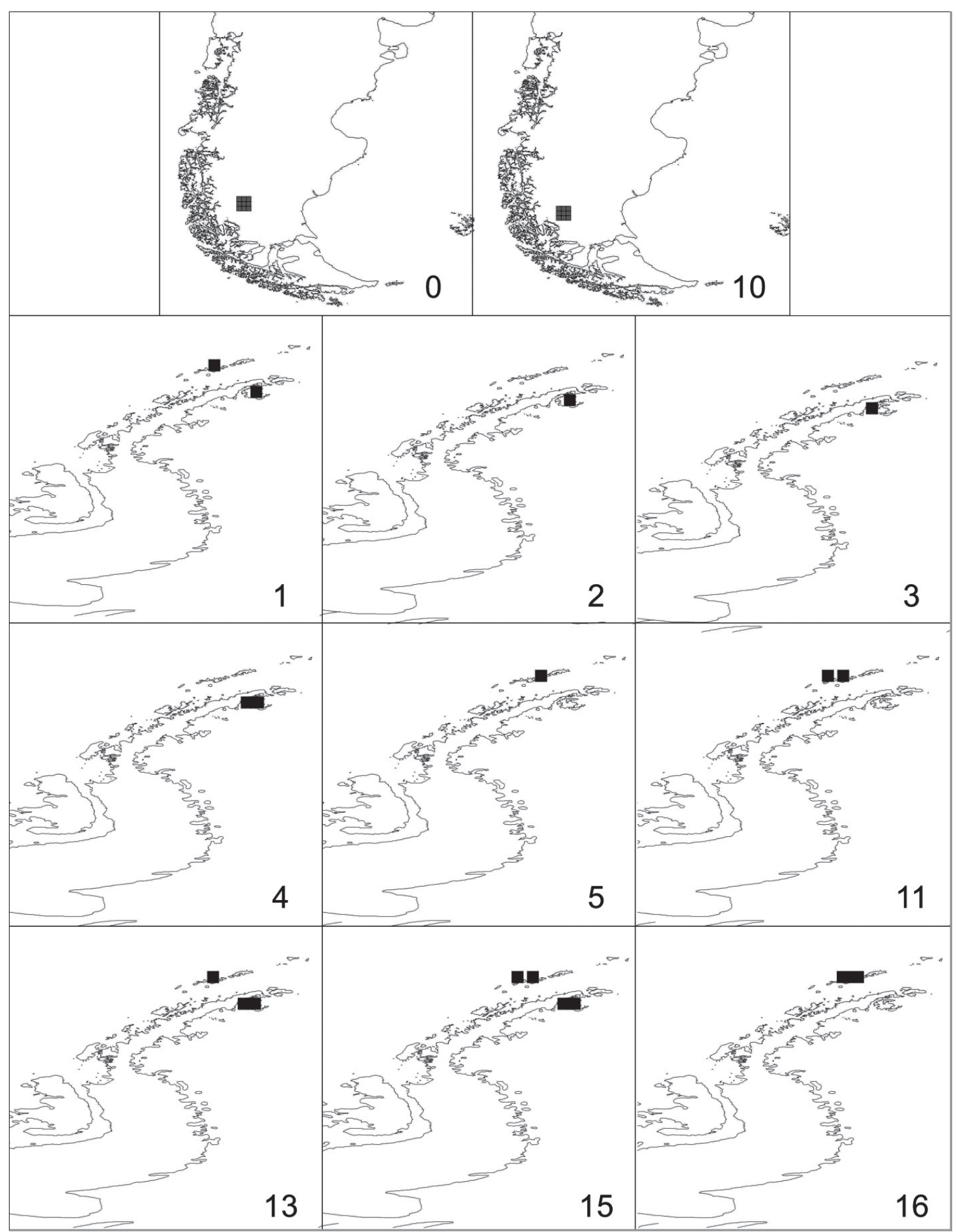

(Fig. 5) 


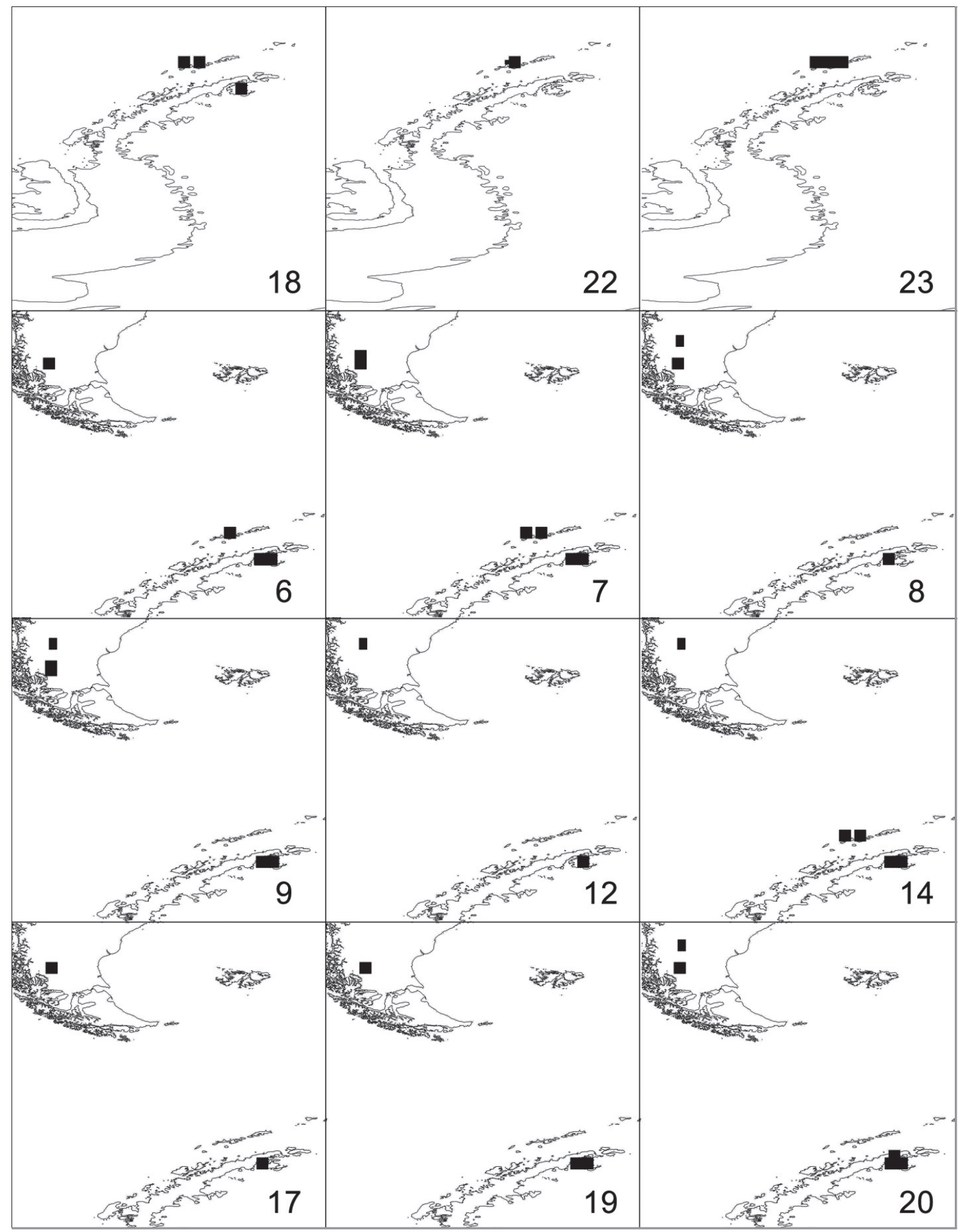

(Fig. 5) 

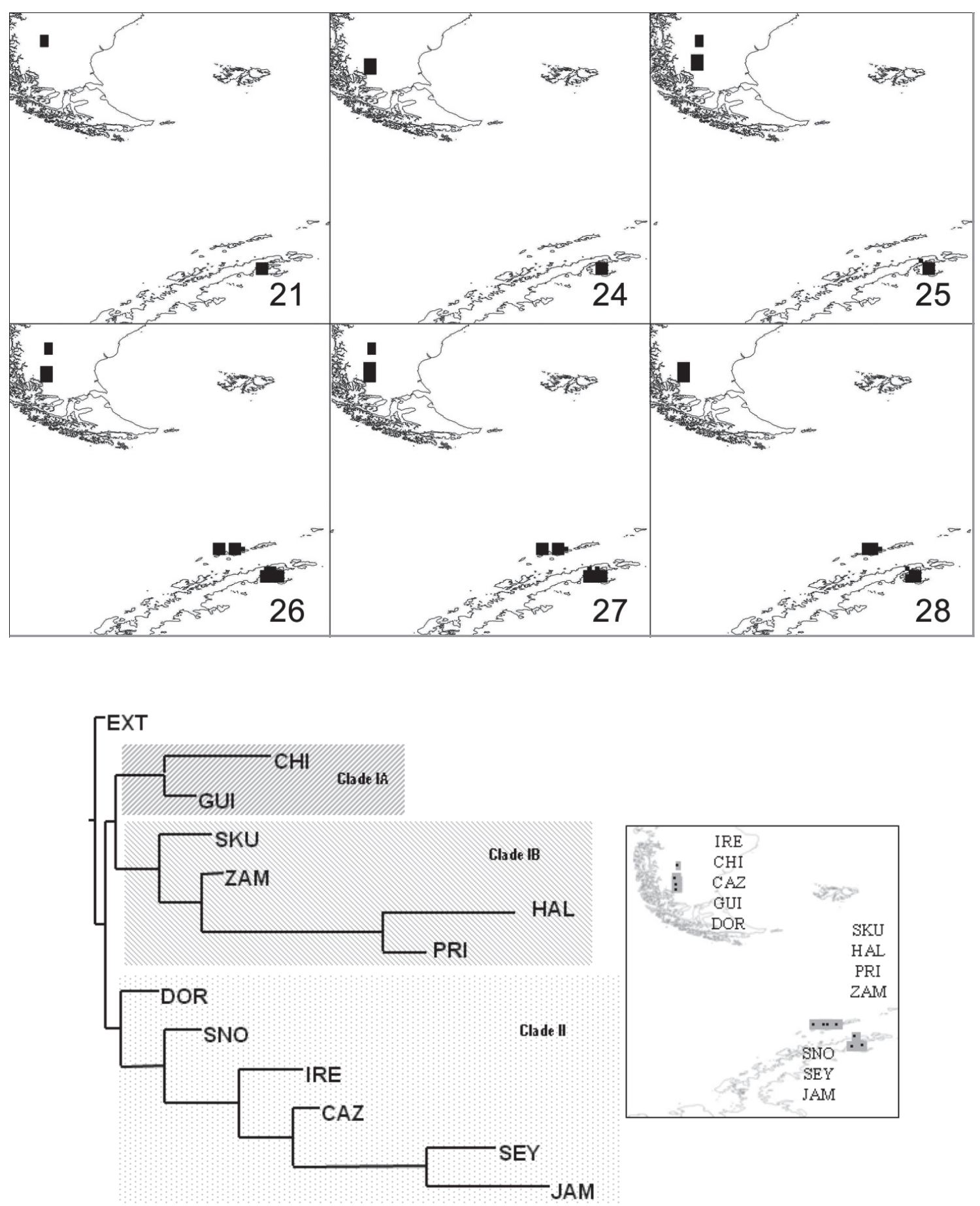

Fig. 5: Diagram of consensus areas (1-28) obtained by AE. The grid in each locality represents an area of $0.25^{\circ}$ $\mathrm{x} 0.25^{\circ}$. The diagram shows localities considered here and areas obtained by PAE relationship, black points correspond to localities and gray dots represent the area considered in the consensus.

Diagrama de Áreas de consenso (1-28) obtenido por AE. La grilla en cada localidad representa un área de $0.25^{\circ} \mathrm{x} 0.25^{\circ}$. El esquema final muestra las localidades consideradas aquí y relación de áreas obtenidas por PAE, los puntos negros corresponden a la coordenada de la localidad considerada y los grises representan el área considerada en el consenso. 


\section{Biogeographical analysis}

The floral diversity and relationships among each locality were analysed using the Parsimony Analysis of Endemicity (PAE) and the Analysis of Endemicity (AE). PAE comprises locations, optimizing the correlation between distributional patterns of taxa, using shared taxa among areas according to the most parsimonious solution (Morrone 1994, Posadas 1996). Rosen (1988) coded the presence or absence of taxa in an area as (1) or (0), respectively. This method is followed here. Our dataset includes 364 taxa of 13 areas (12 localities +1 hypothetical area to root the tree) (Appendix). Data were analyzed with NONA 2.0 (Goloboff 1993) and WinClada (Nixon 1999) using a heuristic search (multiple TBR + TBR). The software was allowed to retain a maximum of 10000 trees with 100 replicates of random addition sequence and an initial 100 trees in each replication. Only informative characters were considered. If two or more resulting cladograms were equally parsimonious, a strict consensus cladogram was generated. The areas of endemism identified and the possible relationships between the localities analyzed by PAE were compared with the result of $\mathrm{AE}$. The $\mathrm{AE}$ was realized by the method of Szumik et al. (2002) and Szumik \& Goloboff (2004). Basically, the method evaluates the consistency of the distribution range of species to a predefined area. The optimality criterion was implemented in NDM/VNDM programs (Goloboff 2005), using default parameters: sets of areas were saved with two or more endemic species (score $>2$ ), while sets of $<0.90$ worst fit were excluded. Optimal sets were chosen when the number of different endemic species was $>40 \%$. Search for endemism was conducted using different proportions of radius size. The best score for endemicity areas was used (fill: $\mathrm{X}=90, \mathrm{Y}=90$; to assume $\mathrm{X}=50, \mathrm{Y}=50$ ). Consensus areas were obtained using $30 \%$ of similarity in species, compared to other areas in the consensus. A flexible consensus is used when at least $50 \%$ of endemic species are in common.

TABLE 1

Areas of consensus for the analysis of flora obtained using, grids of $0.25^{\circ} \times 0.25^{\circ}$. For each area the following parameters are indicated: AI, including individual areas and endemic taxa present.

Áreas de consenso para el análisis de flora obtenidas usando grillas de $0.25^{\circ} \mathrm{x} 0.25^{\circ}$. Para cada área se indica: $\mathrm{AI}$, áreas individuales incluidas y los taxa endémicos presentes.

\begin{tabular}{|c|c|c|}
\hline $\mathrm{AC}$ & AI & $\mathrm{N}^{\circ}$ Taxa \\
\hline 0 & 0 & $\begin{array}{l}0,5,6,8,16,30,31,32,33,34,39,41,55,66,69,76,87,92,93,94,95,99,100,101,104, \\
105,116,117,118,125,127,135,137,138,139,142,144,145,146,153,154,158,159,162, \\
167,168,169,207,208,240,257,260,261,262,263,264,265,266,272,282,295,316,318, \\
337,349,361\end{array}$ \\
\hline 1 & 1 & $2,10,119,126,218,281$ \\
\hline 2 & 2 & $\begin{array}{l}3,4,27,35,36,42,43,45,52,53,58,59,65,74,76,81,85,90,91,112,114,120,124,128, \\
132,136,149,150,155,157,164,165,174,179,180,181,184,189,192,196,210,213,219 \text {, } \\
239,242,244,249,251,252,275,280,284,285,288,289,290,298,300,309,310,311,321 \text {, } \\
329,330,341,359,363\end{array}$ \\
\hline 3 & 3 & 7, 24, 37, 64, 83, 107, 109, 121, 122, 131, 204, 276, 294, 334, 340, 345, 348, 355 \\
\hline 4 & $4,25,26$ & $9,22,23,29,62,63,82,152,278,320,333,360$ \\
\hline 5 & 5 & $11,13,102,108,166,194,201,222,233,235,236,237,243,248,315$ \\
\hline 6 & 6 & $12,56,57,357$ \\
\hline 7 & 7 & $\begin{array}{l}1,17,19,38,47,48,49,51,67,111,115,143,151,171,175,176,177,193,199,211,215 \text {, } \\
216,259,269,273,291,292,322,323,324,331,335\end{array}$ \\
\hline 8 & 8 & $26,88,134,173,186,228,275,283,305,339,352$ \\
\hline 9 & 9 & $28,89,96,178,190,195,198,209,221,224,225,226,231,277,312,313,354$ \\
\hline 10 & 10 & $21,70,187,307,351$ \\
\hline 11 & 11 & $86,214,286$ \\
\hline 12 & 12,15 & $97,98,205,206,220,325$ \\
\hline
\end{tabular}




\begin{tabular}{lll}
\hline AC & AI & \\
\hline 13 & 13 & $111,113,129,130,147,188,238,297,302,306,314,318$ \\
14 & 14 & $156,165,241$ \\
15 & 16 & $253,303,308$ \\
16 & 17 & $44,46,79,197,299$ \\
17 & 18 & $202,245,246,293$ \\
18 & $19,20,21$ & $103,223,227,232,254$ \\
19 & 22 & $14,327,358$ \\
20 & 23 & $15,160,161$ \\
21 & 24,27 & $20,78,171,185,203,256,271$ \\
\hline
\end{tabular}

\section{RESULTS}

Both the $\mathrm{PAE}$ and $\mathrm{AE}$ showed results consistent among them (Figs. 4 and 5, Table 1). The heuristic search results in a single most parsimonious tree (Length [L] 292, Consistency Index [CI] 51 and Retention Index [RI] 54; [Fig. 4]). The cladogram is divided in two main branches: one cluster grouping to Patagonia and King George Island localities in one branch, and Patagonian and James Ross Basin localities in the second. Some elements are exclusive for the Las Chinas and Cerro Guido outcrops, among them $S$. sehuensis, Cinnamonum, Taeniopteris, Menispermites, P. innopinatus and other Laurophyllum taxa. This is an expected result because of the geographical proximity and stratigraphic affinities between both regions. The clade IB clustered all King George Island localities which share six synapomorphic species of the following genera: Dicotylophyllum, Monimiophyllum, Phyllites and Sterculia. A conspicuous difference exists between the two main branches of Clade I: Clade IA includes the Patagonian localities Las Chinas and Cerro Guido, and Clade IB contains the King George Island outcrops. This latter (Clade IB) contains several taxa related to Nothofagaceae, among them leaves of Nothofagus cretense and pollen of Nothofagidites. Nothofagaceae are absent in Clade IA. The $\mathrm{AE}$ analysis generated 33 endemicity areas (Fig. 5, Table 1). The consensus of these areas provided 29 ACs (Fig. 5, Table 1, Appendix). The links between Antarctic and Patagonian localities are supported by several EA (AC 6 to $12,14,17,19,20,21,24$ to 29 , Fig. 5), even though nearby localities such as the Cerro Guido-Las Chinas complex and Dorotea-La Irene, show important differences in their fossil plant composition. The discovery of EAs for the Antarctic Peninsula and Patagonia (AC 0, 10 in Patagonia; 1 to 5, 11, 13, 15, 16, 18, 22, 23 in Antarctica; Fig. 5) is also important to note, because it represents a probable heritage of the vicariant event previous to the CampanianMaastrichtian.

\section{DISCUSSION}

A land bridge between Patagonia and the Antarctic Peninsula is considered to be crucial for the genetic flux between the two continents of terrestrial plants It is known that $\mathrm{CO}_{2}$ reached maximum levels during the early Late Cretaceous and that the region was exposed to westerly winds (Elliot 1988, Del Valle et al. 1992, Hathway 2000). A mountainous terrain is suggested from the proximity to the island arc and may have led to orographic rainfall, moderating temperature extremes and distributing precipitation throughout the year. These were appropriate conditions for the rapid establishment and expansion of a Valdivian type forest. Climatic conditions changed in the Early Campanian and again in the Late Maastrichtian due to the continuous subduction and aggregation of land on the western side of the Antarctic Peninsula (South Shetlands), in addition to a decrease in the global atmospheric 
levels of $\mathrm{CO}_{2}$. These changing environmental conditions could explain the ring-growth pattern in fossil wood from the western part of the isthmus (Francis 1991). On the eastern side, the James Ross Basin was more protected and the changes were less accentuated. The first records of Nothofagidites in Patagonia and Oceania are from the Maastrichtian (Menéndez \& Caccavari de Filici 1975, Romero 1978, Mcloughlin 2001), endorsing the idea of a terrestrial continuity of South America, Antarctica and Australia-New Zealand with a common biogeographic province (Case 1988).

Nothofagaceae are known to occur on the Antarctic Peninsula since the Campanian (Zastawniak \& Szafer 1990, Francis 1991, Dutra 1997, Dutra \& Batten 2000, Dutra 2001, Dutra 2005). The group successfully infiltrated gymnosperm-dominated forest ecosystems, with some opportunistic species of Nothofagus competing for openings in the canopy. This strategy, commonly known as "gap dynamics" (Veblen et al. 1983, Hill 1992, 1994, Veblen et al. 1996), is currently observed in modern Valdivian forests, especially in Andean forests with repeated volcanic disturbance. Species supporting Clades I and II in the present analysis may be related to this strategy, using special microclimatic conditions. From an ecological perspective, both share typical elements of the Valdivian Forests: a canopy dominated by angiosperms and subordinate presence of gymnosperms, and an understory mainly composed of Myrtaceae, Liliaceaea, and Sapotaceae, and ferns such as Blechnaceae and Dicksoniaceae. The sites located in the Tethyan margin, exposed to southern oceanic conditions, are clustered in Clade I and are dominated by angiosperms with subordinated elements of gymnosperms, shrubby ferns and angiosperms. This vegetation significantly differs from the eastern flora (Clade II), which exhibits subtropical taxa mixed with cold temperate elements. This contradictory results regarding Clade II may be explained by a difference in climatic conditions, While floral assemblages lumped in Clade II were exposed to the South Atlantic-Weddell currents, and, westerly winds and moist or/and a previous vicariant event differentially isolated Patagonian plants of Clade I from the northwestern Antarctic Peninsula (South Shetland Islands) and the northeastern Antarctic Peninsula
(James Ross Basin). Unfortunately, the subductive activity along the western border of the Antarctic Peninsula may have erased physical evidence for this hypothesis along the western border of the Magallanes Basin. Clades IA and IB share morphotypes of Sterculiaceae, neotropical trees and shrubs, which were abundant in Cretaceous Patagonian localities. Clade II clusters the Patagonian localities of Dorotea, La Irene and Cazador Hill with the James Ross Basin localities of Seymour Island, James Ross Island and Snow Hill Island. This clade is supported by a few palynomorphs, with Snow Hill Island and Dorotea sites in a basal position. Seymour Island and James Ross Island are well structured with numerous synapomorphic species of Olacaceae, Proteaceae, Bombacaceae, Podocarpaceae, Aquilafoliaceae and Casuarinaceae. Some are tropical in origin, such as Olacaceae, a Gondwana group of mangroves with a wide record during the Paleogene of South America, New Zealand and Africa (Muller 1981); they indicate megathermal and high rainfall conditions. Other taxa, such as Bombacaceae and Aquilafoliaceae were subtropical to tropical elements of the Maastrichtian-Danian (Prámparo et al. 2007). Proteaceae, as well the conifers Araucariacites, Microcarcharidites and Dacrycarpus, show temperate affinities. Clade IIA also contains Arecipites, a taxon with affinities to Palmae (Poole et al. 2005), Arecaceae or Liliaceae (Macphail \& Cantrill 2006), even though their simple type of pollen has frequently been assigned to tree ferns such as Cyathidites and palms. Arecipites is frequently used as a climate proxy indicative of warm conditions and intolerance to long and cold freezing winters (Box 1981). Nevertheless, this interpretation may be erroneous, because other similar families such as Liliaceae, produce structurally identical types of pollen (Erdtman 1971, Skog 1988). Indeed, Palmae have been reported in the same area of Antarctica by Askin (1992), even including Monosulcites minutiscabratus (Baldoni \& Barreda 1986) and Longaperites (Baldoni \& Medina 1989). Modern Palmae are present in cool-temperate Austral ecosystems, among them the Chilean Jubaea chilensis, near Valparaíso, or Rhopalostylis sapida, the Nikau palm, in New Zealand and the Chatham Islands. 
In both, PAE and AE analyses, nearby localities such as the Cerro Guido-Las Chinas complex and Dorotea-La Irene show important differences in their floral composition. This reinforces the idea that coeval sedimentary environments differed at short distance. Nothofagaceae are completely absent at Cerro Guido and Las Chinas and are the dominant element in the Dorotea-La Irene assemblages. This important difference may result from diverging microclimates, similar to the differences that today exist between the western and eastern side of the Patagonian Andes. It is nevertheless evident that localities to the west of the hypothetical isthmus between South America and Antarctica are linked, and that a similar link existed between sites located to the east, such as the James Ross Basin, Dorotea and La Irene. However, these biotical differences may reflect another condition: that the outcrops of the Chinas-Cerro Guido may represent the instant before the massive invasion of Nothofagus from Antarctica to Patagonia. Therefore, Dorotea and La Irene outcrops belong to the end-Maastrichtian interval. Unfortunately, the physical evidence for the western bridge is lost today due to the subduction. The mix of tropical and temperate South American-Australian Antarctic taxa in Maastrichtian localities of northern Magallanes basin is also noteworthy and this area likely represents the "birth place" for the Valdivian forest.

ACKNOWLEDGEMENTS: We are grateful to the crew of "Estancia Cerro Guido" for their support for our field campaigns to this area, the logistic team of the Chilean Antarctic Institute and the Chilean Navy for their important role in the Antarctic campaigns and to FONDECYT 11080223 (2009-2011), BMBF CHL 10A/09 for their financial support. We also thank Prof. Sylvia Palma-Heldt for her collaborative efforts to improve Chilean palaeobotany.

\section{LITERATURE CITED}

ASKIN RA (1992) Late Cretaceous-early Tertiary Antarctic outcrop evidence for past vegetation and climates, in The Antarctic Paleoenvironment: A Perspective on Global Change: Part One, Antarct. Res. Ser., vol. 56, edited by J. P. Kennett and D. A. Warkne, pp. 61-73, AGU, Washington, D. C.

AXELROD DI (1984) An interpretation of Cretaceous and Tertiary biota in the Polar Regions. Palaeogeography, Palaeoclimatology, Palaeoecology 45: 105-147.
BALDONI AM \& F MEDINA (1989) Fauna y microflora del Cretácico, en Bahía Brandy, isla James Ross, Antártida. Serie Científica INACH (Chile) 39: 4358.

BALDONI AM \& V BARREDA (1986) Estudio palinológico de las Formaciones Lopez de Bertodano y Sobral, Isla Vicecomodoro Marambio, Antartida. Boletín Instituto de Geociéncias Universidad de Sao Paulo (Brasil) 17: 89-98.

BIRKENMAJER K and E ZASTAWNIAK (1989) Late Cretaceous-Early Tertiary floras of King George Island, West Antarctica: Their stratigraphic distribution and palaeoclimatic significance. In: J.A. Crame (ed.), Origins and Evolution of the Antarctic Biota. Geological Society, London, Special Publications (Great Britain) 47: 227-240.

BIRKENMAJER K (2001) Mesozoic and Cenozoic stratigraphic units in parts of the South Shetland Islands and northern Antarctic Península. Studia Geologica Polonica (Poland) 118: 1-172.

BOX EO (1981) Macroclimate and Plant Forms: An Introduction to Predictive Modeling in Phytogeography. Dr. W. Junk Publishers, The Hague.

CANTRILL DJ (1997). Hepatophytes from the Early Cretaceous of Alexander Island, Antarctica: Systematics and palaeoecology. International Journal of Plant Sciences 158: 476-488.

CANTRILL DJ (2000). A Cretaceous (Aptian) flora from President Head, Snow Island, Antarctica. Palaeontographica Abteilung B-Palaophytologie 253: 153-191.

CANTRILL DJ (2001) Early Oligocene Nothofagus from CRP-3, Antarctica: Implications for the vegetation history. Terra Antarctica (Germany) 8: 401-406.

CANTRILL DJ \& I POOLE (2002) Cretaceous to Tertiary patterns of diversity changes in the Antarctic Peninsula. In: Owen AW \& JA Crame (eds) Palaeobiogeography and Biodiversity Change: A Comparison of the Ordovician and MesozoicCenozoic Radiations, Geological. Society of London Special Publication, London 194:141-152.

CAO L (1992) Late Cretaceous and Eocene palynofloras from Fildes Peninsula, King George Island (South Shetland Islands), Antarctica. In: Yoshida Y (ed) Recent Progress in Antarctic Earth Science: 363-369. Terra Scientific Publishing Company (Terrapus), Tokyo, Japan.

CASE JA (1988) Paleogene floras from Seymour Island, Antarctic Peninsula. In Geology and Paleontology of Seymour Island, Antarctic Peninsula. (Feldmann, R.M.; Woodburne, M.O.; editors). Geological Society of America Memoirs 169: 523-530.

CESARI S, C PARICA, M REMESAL \& F SALANI (1999) Palaeoflora del Cretácico Inferior de peninsula Byers, islas Shetland del Sur, Antártida. Ameghiniana 36: 3-22.

CRAME JA, D PIRRIE, JB RIDING \& MRA THOMSON (1991) Campanian-Maastrichtian (Cretaceous) stratigraphy of the James Ross Island area, Antarctica. Journal of the Geological Society 148: $1125-1140$.

DALZIEL IWD \& R CORTÉS (1972) Tectonic style of the southernmost Andes and the Antarctandes. Proceedings of the 24th International Geological Congress, Montreal, Canada, 3: 316-327.

DALZIEL IWD (1981) Back-arc extension in the southern Andes: A review and critical reappraisal. 
Philosophical Transactions of the Royal Society of London. Series A, Mathematical and Physical Sciences 300: 319-335.

DUTRA TL (1997) Composição e história da vegetação do Cretáceo e Terciário da ilha Rei George, Península Antártica. PhD. Thesis. Instituto Tecnológico em Micropaleontologia, Universidade Federal do Rio Grande do Sul, Porto Alegre, Brasil.

DUTRA TL (2001) Paleoflora da ilha 25 de Mayo, Península Antártica: Contribuição à paleogeografia, paleoclima e para a evolução de Nothofagus. Asociación Paleontológica Argentina, Publicación Especial (Argentina) 8: 29-37.

DUTRA TL (2005) Part II: Leaf assemblages (taphonomy, paleoclimatology and paleogeography). In: Landman NH \& DS Jones (eds) Topics in Geobiology Applied Stratigraphy Koutsoukos: 194-198. Springer, Netherland.

DUTRA TL \& JD BATTEN (2000) Upper Cretacoeus floras of King George Islands, West Antarctica, and their palaeoenviromental and phytogepgraphic implications. Cretaceous Research 21: 181-209.

ELLIOT DH (1988) Tectonic setting and evolution of the James Ross basin, northern Antarctic Peninsula. In: Feldmann RM \& MO Woodburne (eds) Geology and Paleontology of Seymour Island, Antarctic Peninsula 169: 541-555. Geological Society of America, Boulder, USA.

DEL VALLE RA, DH ELLIOT \& DIM MACDONALD (1992) Sedimentary basins on the east flank of the Antarctic Peninsula: proposed nomenclature. Antarctic Science 4: 477-478.

ERDTMAN G (1971) Pollen morphology and plant taxonomy. Angiosperms. Hafner Publishing Company, New York.

FALCON-LANG HJ, DJ CANTRILL \& GJ NICHOLS (2001) Biodiversity and terrestrial ecology of a mid-Cretaceous, high-latitude floodplain, Alexander Island, Antarctica. Journal of the Geological Society 158: 709-724.

FILDANI A, WH CRANE, BW ROMANS, SM HUBBARD \& MR SHULTZ (2007) Overview: Mesozoic through Early Tertiary Stratigraphic Evolution and Deep-water Deposition of the Magallanes Basin, Chile, Studies in Geology of The American Association of Petroleum Geologists (USA) 56: 123-124.

FRANCIS JE (1991) Palaeoclimatic significance of Cretaceous-early Tertiary fossil forests of the Antarctic Peninsula. In: Thomson MRA, A Crame \& JW Thomson (eds) Geological Evolution of Antarctica: 623-627. Cambridge University Press, New York.

FRANCIS JE \& I POOLE (2002) Cretaceous and early Tertiary climates of Antarctica: Evidence from fossil wood. Palaeogeography, Palaeoclimatology, Palaeoecology 182: 47-64.

GOLOBOFF P (1993) NONA (NO NAME) ver. 2.0. Publisher by the autor, Tucumán. URL: http:// www.cladistics.com (Accessed June 2nd 2011).

GOLOBOFF P (2005) NDM/VNDM ver. 2.5. Programs for identification of areas of endemism. URL: http://www.zmuc.dk/public/phylogeny/ endemism (Accessed June 2nd 2011).

HATHWAY B (2000) Continental rift to back-arc basin: Jurassic-Cretaceous stratigraphical and structural evolution of the Larsen Basin, Antarctic Peninsula. Journal of the Geological Society 157: 417-32.
HILL RS (1992) Nothofagus: Evolution from a southern perspective. Trends in Ecology \& Evolution 7: 190-194.

HILL RS (1994) The history of selected Australian taxa. In: Hill RS (ed) History of the Australian Vegetation: Cretaceous to Recent: 390-419, Cambridge University Press, Cambridge.

HUBER BT (1998) Tropical paradise at Cretaceous poles? Science 282: 2199-2200.

HUNT RJ \& I POOLE (2003) Paleogene West Antarctic climate and vegetation history in light of new data from King George Island. In: Wing SL, PD Gingerich, B Schmitz \& E Thomas (eds) Causes and consequences of globally warm climates in the early Paleogene 369: 395-412. Geological Society of America, Boulder, USA.

INESON JR, JA CRAME \& MRA THOMSON (1986). Lithostratigraphy of the Cretaceous strata of west James Ross Island, Antarctica. Cretaceous Research 7: 141-159.

KATZ HR (1963) Revision of Cretaceous stratigraphy in Patagonian Cordillera of Última Esperanza, Magallanes province, Chile. American Association of Petroleum Geologists Bulletin (USA) 47: 50624.

LAWVER LA, IWD DALZIEL, IO NORTON \& LM GAHAGAN (2009) The PLATES 2009 Atlas of Plate Reconstructions (750 Ma to Present Day), PLATES Progress Report No. 325-0509, University of Texas Technical Report (USA) 196: 32.

LEPPE M, W MICHEA, C MUÑOZ, S PALMA-HELDT \& F FERNANDOY (2007) Paleobotany of Livington Island: The first report of a Cretaceous fossil flora from Hannah Point. In: Cooper AK \& CR Raymond (ed) Antarctica: A keystone in a changing world: 145 National Academies Press(USA).

MACELLARI CE, CA BARRIO \& MJ MANASSERO (1989) Upper Cretaceous to Paleocene depositional sequences and sandstone petrography of Southwestern Patagonia (Argentina and Chile). Journal of South American Earth Sciences 2: 223-239.

MACELLARI CE (1988) Late Cretaceous Kossmaticeratidae (Ammonoidea) from the Magallanes Basin, Chile. Journal of Paleontology 62: 889-905.

MACPHAIL M \& DJ CANTRILL (2006) Age and implications of the Forest Bed, Falkland Islands, southwest Atlantic Ocean: Evidence from fossil pollen and spores. Palaeogeography, Palaeoclimatology, Palaeoecology 240: 602-629.

MALUMIÁN N \& A CARAMÉS (1997) Upper Campanian-Paleogene from the Río Turbio coal measures in southern Argentina: Micropaleontology and the Paleocene/Eocene boundary. Journal of South American Earth Sciences 10: 189-201.

MARENSSI S, V GULERA, S CASADIO, R GUERSTEIN \& O PAPU (2004) Sedimentology and palynology of the Calafate Formation (Maastrichtian), Austral Basin, Southern Patagonia, Argentina. Cretaceous Research 25: 907-918.

MCLOUGHLIN S (2001) The breakup history of Gondwana and its impact on pre-Cenozoic floristic provincialism. Australian Systematic Botany 49: 271-300.

MENÉNDEZ CA \& MA CACCAVARI de FILICI (1975) Las especies de Nothofagidites (polen fósil de Nothofagus) de sedimentos Terciarios y Cretácicos 
de Estancia La Sara. Norte de Tierra del Fuego, Argentina. Ameghiniana 12: 165-183.

MORRONE JJ (1994) On the identification of areas of endemism. Systematic Biology 43: 438-441.

MULLER J (1981) Fossil pollen records of extant angiosperms. Botanical Review 47: 1-142.

NÁÑEZ C \& N MALUMIÁN (2008) Paleobiogeografía y paleogeografía del Maastrichtiano marino de Patagonia, Tierra del Fuego y de la Plataforma Continental Argentina basada en foraminíferos bentónicos. Revista Española de Paleontología (Spain) 23: 273-300.

NATLAND ML, E GONZÁLEZ, A CAÑÓN \& M ERNST (1974) A system of stages for correlation of Magallanes Basin sediments. Geological Society of America Memoir (USA) 139: 1-126.

NIXON KC (1999) Winclada (BETA) ver. 0.9.9. Published by the author, Ithaca.

NELSON PHH (1975) The James Ross Island volcanic group of north-east Graham Land. British Antarctic Survey, Scientific Reports (Great Britain) 54: 1-62.

PANKHURST RJ \& JL SMELLIE (1983) K-Ar geochronology of the South Shetland Islands, lesser Antarctica: Apparent lateral migration of Jurassic to Quaternary island arc volcanism. Earth and Planetary Science Letters 66: 214-212.

PARDO J, W STINNESBECK, E FREY, M FERNÁNDEZ, L RIVAS, C SALAZAR \& M LEPPE (2012) An ichthyosaurian forefin from the Lower Cretaceous Zapata Formation of southern Chile: implications for morphological variability within Platypterygius. Palaeobiodiversity and Palaeoenvironments (Germany) 92: 287-294.

PIRRIE D, JA CRAME, SA LOMAS \& JB RIDING (1997) Late Cretaceous stratigraphy of the Admiralty Sound Region, James Ross Basin, Antarctica. Cretaceous Research 18: 109-137.

POOLE I, RJ HUNT \& DJ CANTRILL (2001) A fossil wood flora from King George Island: Ecological implications for an Antarctic Eocene vegetation. Annals of Botany 88: 33-54.

POOLE I, AMW MENNEGA \& DJ CANTRILL (2003) Valdivian ecosystems in the late Cretaceous and early Tertiary of Antarctica as evidenced from fossil wood. Review of Palaeobotany and Palynology 124: 9-27.

POOLE I, D CANTRILL \& T UTESCHER (2005) A multi-proxy approach to determine Antarctic terrestrial palaeoclimate during the Late Cretaceous and early Tertiary. Palaeogeography, Palaeoclimatology, Palaeoecology 222: 95-121.

POOLE I \& DJ CANTRILL (2006) Cretaceous and Cenozoic vegetation of Antarctica integrating the fossil wood record. Geological Society, London, Special Publications (Great Britain) 258: 63-81.

POSADAS P (1996) Distributional patterns of vascular plants in Tierra del Fuego: A study applying parsimony analysis of endemicity (PAE). Biogeographica (Netherlands) 72: 161-177.

POVILAUSKAS L, V BARREDA \& S MARENSSI (2008). Polen y esporas de la Formación La Irene (Maastrichtiano), sudoeste de la provincia de Santa Cruz, Argentina: primeros resultados. Geobios 41: 819-831.

PRÁMPARO MB, M QUATTROCCHIO, MA GANDOLFO, M ZAMALOA \& E ROMERO (2007) Historia evolutiva de las angiospermas (CretácicoPaleógeno) en Argentina a través de los registros paleoflorísticos. Ameghiniana 11: 157-172.
RICCARDI AC \& EO ROLLERI (1980) Cordillera Patagónica Austral. In: Turner JC (ed) Simposio de Geología Regional Argentina. Academia Nacional de Ciencias de Córdoba (Argentina) 2: 1173-1306.

RIDING JB \& JA CRAME (2002) Aptian to Coniacian (Early-Late Cretaceous) palynostratigraphy of the Gustav Group, James Ross Basin, Antarctica. Cretaceous Research, 23: 739-760.

ROMERO EJ (1978) Paleoecología y paleofitogeografía de las tafofloras del Cenofitico de Argentina y áreas vecinas. Ameghiniana 15: 209-226.

ROSEN BR (1988) From fossils to earth history: Applied historical biogeography. In: Myers AA \& PS Giller (eds) Analytical biogeography: An integrated approach to the study of animal and plant distributions: 437-481, Chapman \& Hall, London.

RUSSO A, MA FLORES \& H DI BENEDETTO (1980) Patagonia austral extraandina. $2^{\circ}$ Simposio Geología Regional Argentina. Academia Nacional de Ciencias de Córdoba(Argentina) 2: 1431-1462.

SHEN Y (1994) Subdivision and correlation of Cretaceous to Paleogene volcano-sedimentary sequence from Fildes Peninsula, King George Island, Antarctica. In: Shen Y (ed) Stratigraphy and palaeontology of Fildes Peninsula, King George Island, Antarctic 3: 1-36. Monograph Science Press, Beijing, China.

SKOG JE (1988) Reassignment of Aspidium heterophyllum to a new genus in the family Matoniaceae. American Journal of Botany 75: 1120-1129.

SMELLIE JL, RJ PANKHURST, MRA THOMSON \& RES DAVIES (1984) The geology of the South Shetland Islands: VI. Stratigraphy, geochemistry and evolution. British Antarctic Survey, Scientific Report (Great Britain) 87: 1-85.

SUÁREZ M (1979) A late Mesozoic island arc in the southern Andes, Chile. Geological Magazine 116: 181-190.

SUÁREZ M, R DE LA CRUZ, M BELL \& A DEMANT (2009) Cretaceous slab segmentation in southwestern Gondwana. Geological Magazine 147: 193-205.

SZUMIK, C \& P GOLOBOFF (2004) Areas of endemism. An improved optimality criterion. Systematic Biology 53: 968-977.

SZUMIK CF, P CUEZZO, P GOLOBOFF \& A CHALUP (2002) An optimality criterion to determine areas of endemism. Systematic Biology 51: 806-816.

TAYLOR EL, TN TAYLOR \& R CUNEO (1992) The present is not the key to the past: A polar forest from the Permian of Antarctica. Science 257: 16751677.

TORRES T, G BARALE, F THIEVERNARD, M PHILIPPE \& H GALLEGUILLOS (1997) Morfologia y sistemática de la flora del Cretácico Inferior de President Head, isla Snow, archipiélago de las Shetland del Sur, Antártica. Serie Cientifica INACH (Chile) 2: 15-50.

UPCHURCH JR, BL OTTO-BLIESNER \& C SCOTESE (1998) Vegetation-atmosphere interactions and their role in global warming during the latest Cretaceous. Philosophical Transactions of the Royal Society of London B 353: 97-112.

VEBLEN TT, FM SCHLEGEL \& JV OLTREMARI (1983) Temperate broadleafed evergreen forests of South America. In: Ovington JD (ed) Ecosystems of the world 10: Temperate broadleafed evergreen forests: 5-31. Elsevier, Amsterdam. 
VEBLEN TT, C DONOSO, T KITZBERGER \& AJ REBERTUS (1996) Ecology of southern Chilean and Argentinean Nothofagus forests. In: Veblen TT, RS Hill \& J Read (eds) The Ecology and biogeography of Nothofagus forests: 293-353. Yale University Press, New Haven.

ZASTAWNIAK E \& W SZAFER (1990) Late Cretaceous leaf flora of King George Island, west Antarctica.
In: Procedures symposium: Palaeofloristic and palaeoclimatic changes in the Cretaceous and Tertiary: 81-85. Geological Survey Publisher, Praga, Czech Republic.

ZINSMEISTER W (1987) Cretaceous paleogeography of Antarctica. Palaeogeography, Palaeoclimatology, Palaeoecology 59: 197-206.

\section{APPENDIX}

Data matrix used for the PAE and AE analyses. First column: taxa number (character). Second column: Scientific name of taxa. Third column: presence/absence matrix in localities EXT, Outgroup; IRE, La Irene; CHI, Las Chinas; CAZ, C ${ }^{\circ}$ Cazador; DOR, Dorotea; GUI, $\mathrm{C}^{\circ}$ Guido; SNO, Snow Hill Island; SEY, Seymour Island; JAM, James Ross Island; SKU, Skua Bay; HAL, Half Three Point; PRI, Price Point and ZAM, Zamek Hill (The letters A-M correspond to the sequence of localities above).

Matriz de datos utilizada para los análisis PAE y AE. Primera columna: el número de taxa (caracteres). Segunda columna: nombre taxa. Tercera columna: matriz de presencia/ausencia en localidades EXT, Outgroup; IRE, La Irene; CHI, Las Chinas; CAZ, C Cazador; DOR, Dorotea; GUI, C ${ }^{\circ}$ Guido; SNO, Snow Hill Island; SEY, Seymour Island; JAM, James Ross Island; SKU, Skua Bay; HAL, Half Three Point; PRI, Price Point and ZAM, Zamek Hill (Las letras A-M se corresponden con las localidades en el orden indicado).

\begin{tabular}{|c|c|c|c|c|c|c|c|c|c|c|c|c|c|c|}
\hline $\mathrm{N}^{\circ}$ taxa & PALINOMORPHS & A & $\mathrm{B}$ & $\mathrm{C}$ & $\mathrm{D}$ & $\mathrm{E}$ & $\mathrm{F}$ & $\mathrm{G}$ & $\mathrm{H}$ & I & $\mathrm{J}$ & $\mathrm{K}$ & $\mathrm{L}$ & $\mathrm{M}$ \\
\hline 0 & Abiyineaepollenites microalatus Delcourt \& Sprumont & 0 & 0 & 0 & 0 & 0 & 0 & 0 & 0 & 0 & 0 & 1 & 0 & 0 \\
\hline 2 & Aequitriradites spinulosus Cookson \& Dettmann & 0 & 0 & 0 & 0 & 0 & 0 & 0 & 0 & 1 & 0 & 1 & 0 & 0 \\
\hline 3 & Ailanthipites sp. Wodehouse & 0 & 0 & 0 & 0 & 0 & 0 & 0 & 0 & 1 & 0 & 0 & 0 & 0 \\
\hline 4 & Alisporites grandis (Cookson) Dettmann & 0 & 0 & 0 & 0 & 0 & 0 & 0 & 0 & 1 & 0 & 0 & 0 & 0 \\
\hline 5 & Alsophilidites kerguelensis Cookson & 0 & 0 & 0 & 0 & 0 & 0 & 0 & 0 & 0 & 0 & 1 & 0 & 0 \\
\hline 6 & Alsophilidites sp. Cookson & 0 & 0 & 0 & 0 & 0 & 0 & 0 & 0 & 0 & 0 & 1 & 0 & 0 \\
\hline 7 & Amosopollis cruciformis Cookson \& Balme & 0 & 0 & 0 & 0 & 0 & 0 & 0 & 1 & 0 & 0 & 0 & 0 & 0 \\
\hline 8 & Anacardites pichileufensis Berry & 0 & 0 & 0 & 0 & 0 & 0 & 0 & 0 & 0 & 1 & 1 & 0 & 0 \\
\hline 9 & Anacolosidites sectus Partridge & 0 & 0 & 0 & 0 & 0 & 0 & 0 & 1 & 1 & 0 & 0 & 0 & 0 \\
\hline 10 & Appendicisporites sp. Saad \& Ghazaly & 0 & 0 & 0 & 0 & 0 & 0 & 0 & 0 & 1 & 0 & 1 & 0 & 0 \\
\hline 12 & Araucariacites australis Cookson & 0 & 0 & 0 & 1 & 0 & 0 & 0 & 1 & 1 & 0 & 1 & 0 & 0 \\
\hline 14 & Araucariacites sp. Courtinat \& Jenny & 0 & 0 & 1 & 1 & 0 & 0 & 0 & 1 & 1 & 0 & 1 & 1 & 0 \\
\hline 15 & Arecipites minutiscabratus (McIntyre) Milne & 0 & 1 & 0 & 1 & 0 & 0 & 0 & 1 & 0 & 0 & 0 & 0 & 0 \\
\hline 16 & Arecipites sp. Wodehouse & 0 & 1 & 1 & 1 & 0 & 0 & 0 & 0 & 1 & 0 & 0 & 0 & 0 \\
\hline 17 & Asterisporites sp. Venkatachala \& Rawat & 0 & 0 & 0 & 0 & 0 & 0 & 0 & 0 & 0 & 0 & 1 & 0 & 0 \\
\hline 19 & Baculatisporites comaumensis (Cookson ) Potonie & 0 & 1 & 0 & 1 & 1 & 0 & 0 & 1 & 1 & 0 & 0 & 0 & 0 \\
\hline 20 & $\begin{array}{c}\text { Baculatisporites kachaikensis Llorens \& } \\
\text { Archangelsky }\end{array}$ & 0 & 0 & 1 & 0 & 0 & 0 & 0 & 0 & 0 & 0 & 0 & 0 & 0 \\
\hline 21 & Baculatisporites sp. Pflug \& Thomson & 0 & 1 & 0 & 0 & 1 & 0 & 0 & 1 & 1 & 0 & 1 & 1 & 0 \\
\hline
\end{tabular}




\begin{tabular}{|c|c|c|c|c|c|c|c|c|c|c|c|c|c|c|}
\hline $\mathrm{N}^{\circ}$ taxa & PALINOMORPHS & A & $\mathrm{B}$ & $\mathrm{C}$ & $\mathrm{D}$ & $\mathrm{E}$ & $\mathrm{F}$ & G & $\mathrm{H}$ & $\mathrm{I}$ & $\mathrm{J}$ & $\mathrm{K}$ & $\mathrm{L}$ & M \\
\hline 22 & Baculatisporites turbioensis Archangelsky & 0 & 0 & 0 & 0 & 1 & 0 & 0 & 0 & 1 & 0 & 0 & 0 & 0 \\
\hline 23 & Beaupreaidites elegansiformis Cookson & 0 & 0 & 0 & 0 & 0 & 0 & 0 & 1 & 1 & 0 & 0 & 0 & 0 \\
\hline 24 & Beaupreaidites sp. Cookson ex R. Potonié & 0 & 0 & 0 & 0 & 0 & 0 & 0 & 1 & 1 & 0 & 0 & 0 & 0 \\
\hline 25 & Beaupreaidites verrucosus Cookson & 0 & 0 & 0 & 0 & 0 & 0 & 0 & 1 & 0 & 0 & 0 & 0 & 0 \\
\hline 27 & Biretisporites sp. cf. potoniaei Delcourt \& Sprumont & 0 & 0 & 1 & 1 & 0 & 0 & 0 & 0 & 1 & 0 & 1 & 0 & 0 \\
\hline 26 & Biretisporites spectabilis Dettmann & 0 & 0 & 0 & 1 & 0 & 0 & 0 & 0 & 0 & 0 & 0 & 0 & 0 \\
\hline 28 & Biryisporites sp. Delcourt \& Sprumont & 0 & 0 & 0 & 0 & 0 & 0 & 0 & 0 & 1 & 0 & 0 & 0 & 0 \\
\hline 30 & Bombacacidites bombaxoides Couper & 0 & 0 & 0 & 0 & 0 & 0 & 0 & 1 & 1 & 0 & 0 & 0 & 0 \\
\hline 31 & Brachysporisporites antarcticus Song \& Cao & 0 & 0 & 0 & 0 & 0 & 0 & 0 & 0 & 0 & 0 & 1 & 0 & 0 \\
\hline 32 & Brachysporisporites grandus Song \& Cao & 0 & 0 & 0 & 0 & 0 & 0 & 0 & 0 & 0 & 0 & 1 & 0 & 0 \\
\hline 33 & Brachysporisporites longovatus Song \& Cao & 0 & 0 & 0 & 0 & 0 & 0 & 0 & 0 & 0 & 0 & 1 & 0 & 0 \\
\hline 34 & Brachysporisporites ovoidus Song \& Cao & 0 & 0 & 0 & 0 & 0 & 0 & 0 & 0 & 0 & 0 & 1 & 0 & 0 \\
\hline 35 & Brachysporisporites sp. Lange \& Smith & 0 & 0 & 0 & 0 & 0 & 0 & 0 & 0 & 0 & 0 & 1 & 0 & 0 \\
\hline 36 & Brassospora sp. Hill and Read & 0 & 0 & 0 & 0 & 0 & 0 & 0 & 0 & 1 & 0 & 0 & 0 & 0 \\
\hline 37 & Camarazonosporites ambigens (Fradkina) Playford & 0 & 0 & 0 & 0 & 0 & 0 & 0 & 0 & 1 & 0 & 0 & 0 & 0 \\
\hline 38 & Camarazonosporites ohaiensis (Couper) & 0 & 0 & 0 & 0 & 0 & 0 & 0 & 1 & 0 & 0 & 0 & 0 & 0 \\
\hline 42 & Ceratosporites equalis Cookson \& Dettmann & 0 & 1 & 0 & 0 & 0 & 0 & 0 & 1 & 1 & 0 & 0 & 0 & 0 \\
\hline 43 & Cibotiumspora sp. Jersey \& Raine & 0 & 0 & 0 & 0 & 0 & 0 & 0 & 0 & 0 & 0 & 1 & 0 & 0 \\
\hline 44 & Cicatricosisporites australiensis (Cookson) Potonié & 0 & 1 & 0 & 0 & 0 & 0 & 0 & 0 & 1 & 0 & 0 & 0 & 0 \\
\hline 45 & Cicatricosisporites hughesii Dettmann & 0 & 0 & 0 & 0 & 0 & 0 & 0 & 0 & 1 & 0 & 0 & 0 & 0 \\
\hline 46 & Cicatricosisporites sp. Potonié \& Gellyich & 0 & 1 & 0 & 0 & 0 & 0 & 1 & 0 & 1 & 0 & 0 & 0 & 0 \\
\hline 48 & Cingulatisporites scabratus Thomson & 0 & 0 & 0 & 0 & 0 & 0 & 0 & 0 & 1 & 0 & 0 & 0 & 0 \\
\hline 47 & Cingutriletes australis Pierce & 0 & 0 & 0 & 0 & 0 & 0 & 0 & 0 & 1 & 0 & 0 & 0 & 0 \\
\hline 53 & Classopollis sp. Danzé-Corsin \& Laveine & 0 & 0 & 1 & 0 & 0 & 0 & 0 & 0 & 0 & 0 & 0 & 0 & 0 \\
\hline 55 & Clavamonocolpites polygonalis Askin & 0 & 0 & 0 & 0 & 0 & 0 & 0 & 0 & 1 & 0 & 0 & 0 & 0 \\
\hline 54 & Clavatipollenites hughesii Couper & 0 & 0 & 0 & 0 & 0 & 0 & 0 & 0 & 1 & 0 & 0 & 0 & 0 \\
\hline 56 & Clavatipollenites sp. González-Guzmán & 0 & 1 & 1 & 0 & 0 & 0 & 0 & 0 & 1 & 0 & 1 & 1 & 0 \\
\hline 57 & Clavifera jachromensis Bolchovitina & 0 & 0 & 0 & 0 & 0 & 0 & 0 & 0 & 0 & 0 & 1 & 0 & 0 \\
\hline 58 & Clavifera sp. Bolchovitina & 0 & 0 & 0 & 1 & 0 & 0 & 0 & 1 & 1 & 0 & 1 & 0 & 0 \\
\hline 59 & Clavifera triplex (Bolkhovitina) Bolkhovitina & 0 & 0 & 0 & 1 & 0 & 0 & 0 & 1 & 1 & 0 & 1 & 0 & 0 \\
\hline 60 & Compositoipollenites tarragoensis Truswell y Owens & 0 & 0 & 0 & 0 & 0 & 0 & 0 & 0 & 1 & 0 & 0 & 0 & 0 \\
\hline 61 & Contignisporites cooksoniae (Balme) Dettmann & 0 & 0 & 0 & 0 & 0 & 0 & 0 & 0 & 1 & 0 & 0 & 0 & 0 \\
\hline 64 & Cranwellia sp. Srivastava & 0 & 0 & 0 & 0 & 0 & 0 & 0 & 1 & 1 & 0 & 1 & 0 & 0 \\
\hline 65 & Cranwellia striata (Couper) Srivastava & 0 & 0 & 0 & 0 & 0 & 0 & 0 & 1 & 1 & 0 & 0 & 0 & 0 \\
\hline 62 & Cranwellipollis palisadus (Couper) & 0 & 0 & 0 & 0 & 0 & 0 & 0 & 1 & 1 & 0 & 0 & 0 & 0 \\
\hline 63 & Cranwellipollis sp. Martin y Harris & 0 & 0 & 0 & 0 & 0 & 0 & 0 & 1 & 1 & 0 & 0 & 0 & 0 \\
\hline 66 & $\begin{array}{c}\text { Cranwellipollis subpalisadus (Couper) Martin y } \\
\text { Harris }\end{array}$ & 0 & 0 & 0 & 0 & 0 & 0 & 0 & 1 & 0 & 0 & 0 & 0 & 0 \\
\hline 67 & $\begin{array}{c}\text { Crybelosporites striatus (Cookson y Dettmann) } \\
\text { Dettmann }\end{array}$ & 0 & 0 & 0 & 0 & 0 & 0 & 0 & 0 & 1 & 0 & 0 & 0 & 0 \\
\hline 70 & Cupanieidites orthoteicus Cookson \& Pike & 0 & 0 & 0 & 0 & 0 & 0 & 0 & 1 & 1 & 0 & 0 & 0 & 0 \\
\hline
\end{tabular}




\begin{tabular}{|c|c|c|c|c|c|c|c|c|c|c|c|c|c|c|}
\hline $\mathrm{N}^{\circ}$ taxa & PALINOMORPHS & A & $\mathrm{B}$ & $\mathrm{C}$ & $\mathrm{D}$ & $\mathrm{E}$ & $\mathrm{F}$ & G & $\mathrm{H}$ & I & $\mathrm{J}$ & $\mathrm{K}$ & $\mathrm{L}$ & M \\
\hline 71 & Cupulisporonites megaporus Song \& Cao & 0 & 0 & 0 & 0 & 0 & 0 & 0 & 0 & 0 & 0 & 1 & 0 & 0 \\
\hline 75 & Cyatheacidites annulatus Cookson & 0 & 0 & 0 & 1 & 0 & 0 & 0 & 0 & 1 & 0 & 0 & 0 & 0 \\
\hline 72 & Cyatheacidites sp. L. C. Cookson ex R. Potonié & 0 & 0 & 0 & 1 & 0 & 0 & 0 & 0 & 1 & 0 & 1 & 1 & 0 \\
\hline 73 & Cyathidites australis Couper & 0 & 0 & 0 & 1 & 0 & 0 & 0 & 0 & 1 & 0 & 0 & 0 & 0 \\
\hline 74 & Cyathidites concavus (Bolkhovitina) Dettmann & 0 & 0 & 0 & 0 & 0 & 0 & 0 & 0 & 1 & 0 & 0 & 0 & 0 \\
\hline 75 & Cyathidites minor Couper & 0 & 1 & 1 & 1 & 1 & 0 & 0 & 1 & 1 & 0 & 1 & 0 & 0 \\
\hline 76 & Cyathidites pulchellus Cao & 0 & 0 & 0 & 0 & 0 & 0 & 0 & 0 & 0 & 0 & 1 & 0 & 0 \\
\hline 78 & Cyathidites sp. R. A. Couper & 0 & 1 & 0 & 1 & 1 & 0 & 1 & 1 & 1 & 0 & 1 & 1 & 0 \\
\hline 79 & Cycadopites nitidus Balme & 0 & 1 & 0 & 0 & 0 & 0 & 0 & 0 & 1 & 0 & 0 & 0 & 0 \\
\hline 80 & Cycadopites sp. Wodehouse & 0 & 1 & 0 & 0 & 0 & 0 & 0 & 1 & 1 & 0 & 1 & 1 & 0 \\
\hline 81 & Cyclusphaera sp. W. C. Elsik & 0 & 0 & 0 & 0 & 0 & 0 & 0 & 0 & 1 & 0 & 0 & 0 & 0 \\
\hline 82 & Dacrycarpites australiensis Cookson \& Pike & 0 & 0 & 0 & 0 & 0 & 0 & 0 & 1 & 1 & 0 & 0 & 0 & 0 \\
\hline 83 & Dacrycarpus sp. J. Arnold Arbor & 0 & 0 & 0 & 0 & 0 & 0 & 0 & 1 & 0 & 0 & 0 & 0 & 0 \\
\hline 84 & Dacrydium sp. Lambert & 0 & 0 & 0 & 0 & 0 & 0 & 0 & 1 & 1 & 0 & 1 & 0 & 0 \\
\hline 85 & Dacrydiumites florinii Cookson \& Pike & 0 & 0 & 0 & 0 & 0 & 0 & 0 & 0 & 1 & 0 & 0 & 0 & 0 \\
\hline 86 & Dacrydiumites sp. Hekel & 0 & 0 & 0 & 0 & 0 & 0 & 0 & 1 & 1 & 0 & 1 & 1 & 0 \\
\hline 87 & Deltoidospora hallii Miner & 0 & 0 & 0 & 0 & 0 & 0 & 0 & 0 & 0 & 0 & 1 & 0 & 0 \\
\hline 88 & Deltoidospora microlepioides (Krutzsch) Wang & 0 & 0 & 0 & 0 & 0 & 0 & 0 & 0 & 0 & 0 & 1 & 0 & 0 \\
\hline 89 & Deltoidospora sp. Danzé-Corsin \& Laveine & 0 & 0 & 0 & 1 & 0 & 0 & 0 & 0 & 0 & 0 & 1 & 1 & 0 \\
\hline 90 & Delwynites tuberculatus Askin & 0 & 0 & 0 & 0 & 0 & 0 & 0 & 0 & 1 & 0 & 0 & 0 & 0 \\
\hline 91 & Densoisporites velatus Weyland \& Krieger & 0 & 0 & 0 & 0 & 0 & 0 & 0 & 0 & 1 & 0 & 0 & 0 & 0 \\
\hline 92 & Dicellaesporites antarcticus Song \& Cao & 0 & 0 & 0 & 0 & 0 & 0 & 0 & 0 & 0 & 0 & 1 & 0 & 0 \\
\hline 93 & Dicellaesporites oblongatus Song \& Cao & 0 & 0 & 0 & 0 & 0 & 0 & 0 & 0 & 0 & 0 & 1 & 0 & 0 \\
\hline 94 & Dicellaesporites popovii Elsik & 0 & 0 & 0 & 0 & 0 & 0 & 0 & 0 & 0 & 0 & 1 & 0 & 0 \\
\hline 95 & Dicellaesporites sp. (Elsik) Sheffy \& Dilcher & 0 & 0 & 0 & 0 & 0 & 0 & 0 & 0 & 0 & 0 & 1 & 0 & 0 \\
\hline 99 & Diporicellaesporites antarcticus Song \& Cao & 0 & 0 & 0 & 0 & 0 & 0 & 0 & 0 & 0 & 0 & 1 & 0 & 0 \\
\hline 100 & Diporicellaesporites $s p$. Elsik & 0 & 0 & 0 & 0 & 0 & 0 & 0 & 0 & 0 & 0 & 1 & 0 & 0 \\
\hline 101 & Diporicellaesporites stenosus Song \& Cao & 0 & 0 & 0 & 0 & 0 & 0 & 0 & 0 & 0 & 0 & 1 & 0 & 0 \\
\hline 104 & Dyadosporites obscurus Song \& Cao & 0 & 0 & 0 & 0 & 0 & 0 & 0 & 0 & 0 & 0 & 1 & 0 & 0 \\
\hline 105 & Dyadosporites sp. T. van der Hammen \& Clarke & 0 & 0 & 0 & 0 & 0 & 0 & 0 & 0 & 0 & 0 & 1 & 0 & 0 \\
\hline 106 & Echinosporis sp. Krutzsch & 0 & 0 & 0 & 1 & 0 & 0 & 0 & 0 & 0 & 0 & 1 & 0 & 0 \\
\hline 107 & Echitriporites sp. T. van der Hammen & 0 & 0 & 0 & 0 & 0 & 0 & 0 & 1 & 0 & 0 & 0 & 0 & 0 \\
\hline 110 & Ephedripites notensis (Cookson) Krutzsch & 0 & 0 & 0 & 0 & 0 & 0 & 0 & 0 & 1 & 0 & 0 & 0 & 0 \\
\hline 111 & Equisetosporites sp. Daugherty & 0 & 1 & 0 & 0 & 0 & 0 & 0 & 0 & 0 & 0 & 0 & 0 & 0 \\
\hline 113 & Ericipites scabratus Harris & 0 & 1 & 0 & 0 & 0 & 0 & 0 & 0 & 0 & 0 & 0 & 0 & 0 \\
\hline 114 & Ericipites sp. Wodehouse & 0 & 0 & 0 & 0 & 0 & 0 & 0 & 0 & 1 & 0 & 0 & 0 & 0 \\
\hline 115 & Exesisporites sp. Elsik & 0 & 0 & 1 & 0 & 0 & 0 & 0 & 0 & 0 & 0 & 0 & 0 & 0 \\
\hline 116 & Extrapunctatosporis sp. Krutzsch & 0 & 0 & 0 & 0 & 0 & 0 & 0 & 0 & 0 & 0 & 1 & 0 & 0 \\
\hline 119 & $\begin{array}{c}\text { Foraminisporis dailyi (Cookson \& Dettmann) } \\
\text { Dettmann }\end{array}$ & 0 & 0 & 0 & 0 & 0 & 0 & 0 & 0 & 1 & 0 & 1 & 0 & 0 \\
\hline
\end{tabular}




\begin{tabular}{|c|c|c|c|c|c|c|c|c|c|c|c|c|c|c|}
\hline $\mathrm{N}^{\circ}$ taxa & PALINOMORPHS & A & B & $\mathrm{C}$ & $\mathrm{D}$ & $\mathrm{E}$ & $\mathrm{F}$ & G & $\mathrm{H}$ & I & $\mathrm{J}$ & $\mathrm{K}$ & $\mathrm{L}$ & M \\
\hline 120 & $\begin{array}{c}\text { Foraminisporis asymmetricus (Cookson \& Dettmann) } \\
\text { Dettmann }\end{array}$ & 0 & 0 & 0 & 0 & 0 & 0 & 0 & 0 & 1 & 0 & 0 & 0 & 0 \\
\hline 121 & $\begin{array}{c}\text { Forcipites sabulosus (Dettmann \& Playford ) } \\
\text { Dettmann \& Jarzen }\end{array}$ & 0 & 0 & 0 & 0 & 0 & 0 & 0 & 1 & 0 & 0 & 0 & 0 & 0 \\
\hline 122 & $\begin{array}{l}\text { Forcipites sp. cf. longus (Stover \& Evans) Dettmann } \\
\qquad \& \text { Jarzen }\end{array}$ & 0 & 0 & 0 & 0 & 0 & 0 & 0 & 1 & 0 & 0 & 0 & 0 & 0 \\
\hline 123 & Forcipites sp. Dettmann \& Jarzen & 0 & 0 & 0 & 1 & 0 & 0 & 0 & 1 & 0 & 0 & 0 & 0 & 0 \\
\hline 124 & $\begin{array}{c}\text { Foveogleicheniidites confossus (Hedlund) Norvick \& } \\
\text { Burger }\end{array}$ & 0 & 0 & 0 & 0 & 0 & 0 & 0 & 0 & 1 & 0 & 0 & 0 & 0 \\
\hline 125 & Foveotriletes scrobiculatus (Ross) Potonie' & 0 & 0 & 0 & 0 & 0 & 0 & 0 & 0 & 0 & 0 & 1 & 0 & 0 \\
\hline 126 & Foveotriletes sp. Puri & 0 & 0 & 0 & 0 & 0 & 0 & 0 & 0 & 1 & 0 & 1 & 0 & 0 \\
\hline 127 & Fractisporonites sp. Clarke & 0 & 0 & 0 & 0 & 0 & 0 & 0 & 0 & 0 & 0 & 1 & 0 & 0 \\
\hline 128 & Fuscospora sp. Hill \& Read & 0 & 0 & 0 & 0 & 0 & 0 & 0 & 0 & 1 & 0 & 0 & 0 & 0 \\
\hline 129 & Gabonisporites sp. Boltenhagen & 0 & 1 & 0 & 0 & 0 & 0 & 0 & 0 & 0 & 0 & 0 & 0 & 0 \\
\hline 130 & Gamerroites psilasaccus Archangelsky & 0 & 1 & 0 & 0 & 0 & 0 & 0 & 0 & 0 & 0 & 0 & 0 & 0 \\
\hline 132 & Gemmamonocolpites pilulus Askin & 0 & 0 & 0 & 0 & 0 & 0 & 0 & 0 & 1 & 0 & 0 & 0 & 0 \\
\hline 134 & Gleicheniidites aptianus Llorens & 0 & 0 & 0 & 1 & 0 & 0 & 0 & 0 & 0 & 0 & 0 & 0 & 0 \\
\hline 135 & Gleicheniidites campanianus Cao & 0 & 0 & 0 & 0 & 0 & 0 & 0 & 0 & 0 & 0 & 1 & 0 & 0 \\
\hline 136 & Gleicheniidites cercinidites (Cookson) Dettmann & 0 & 0 & 0 & 0 & 0 & 0 & 0 & 0 & 1 & 0 & 0 & 0 & 0 \\
\hline 137 & Gleicheniidites delcourtii Doring & 0 & 0 & 0 & 0 & 0 & 0 & 0 & 0 & 0 & 0 & 1 & 0 & 0 \\
\hline 138 & Gleicheniidites fildesensis Cao & 0 & 0 & 0 & 0 & 0 & 0 & 0 & 0 & 0 & 0 & 1 & 0 & 0 \\
\hline 139 & Gleicheniidites pachydermus Cao & 0 & 0 & 0 & 0 & 0 & 0 & 0 & 0 & 0 & 0 & 1 & 0 & 0 \\
\hline 140 & Gleicheniidites senonicus Ross & 0 & 1 & 1 & 1 & 0 & 0 & 0 & 1 & 0 & 0 & 1 & 0 & 0 \\
\hline 141 & Gleicheniidites sp. Grigoreva & 0 & 1 & 1 & 1 & 0 & 0 & 0 & 1 & 1 & 0 & 1 & 0 & 0 \\
\hline 142 & Gleicheniidites trivalis Brotzen & 0 & 0 & 0 & 0 & 0 & 0 & 0 & 0 & 0 & 0 & 1 & 0 & 0 \\
\hline 143 & Gleichenites sanmartini Halle emend. Herbst & 0 & 0 & 1 & 0 & 0 & 0 & 0 & 0 & 0 & 0 & 0 & 0 & 0 \\
\hline 144 & Gnetaceaepollenites ellipticus Thiergart & 0 & 0 & 0 & 0 & 0 & 0 & 0 & 0 & 0 & 0 & 1 & 0 & 0 \\
\hline 145 & Gnetaceaepollenites sp. Thiergart & 0 & 0 & 0 & 0 & 0 & 0 & 0 & 0 & 0 & 0 & 1 & 0 & 0 \\
\hline 146 & Gothanipollis bassensis Stover \& Partridge & 0 & 0 & 0 & 0 & 0 & 0 & 0 & 0 & 0 & 0 & 1 & 0 & 0 \\
\hline 147 & Granulatisporites sp. Wilson & 0 & 1 & 0 & 0 & 0 & 0 & 0 & 0 & 0 & 0 & 0 & 0 & 0 \\
\hline 148 & Grapnelispora evansii Stover \& Partridge & 0 & 0 & 0 & 0 & 0 & 0 & 1 & 1 & 0 & 0 & 0 & 0 & 0 \\
\hline 149 & Haloragacidites harrisii (Couper) Harris & 0 & 0 & 0 & 0 & 0 & 0 & 0 & 0 & 1 & 0 & 0 & 0 & 0 \\
\hline 150 & Herkosporites elliotii Stover & 0 & 0 & 0 & 0 & 0 & 0 & 0 & 0 & 1 & 0 & 0 & 0 & 0 \\
\hline 152 & Illexpollenites sp. Partridge & 0 & 0 & 0 & 0 & 0 & 0 & 0 & 1 & 1 & 0 & 0 & 0 & 0 \\
\hline 153 & Inapertisporites obpyriformis Sheffy \& Dilcher & 0 & 0 & 0 & 0 & 0 & 0 & 0 & 0 & 0 & 0 & 1 & 0 & 0 \\
\hline 154 & Inapertisporites solidus Song \& Cao & 0 & 0 & 0 & 0 & 0 & 0 & 0 & 0 & 0 & 0 & 1 & 0 & 0 \\
\hline 155 & Inaperturopollenites laevigatus Takahashi & 0 & 0 & 0 & 0 & 0 & 0 & 0 & 0 & 1 & 0 & 0 & 0 & 0 \\
\hline 156 & Inaperturopollenites sp. Pflug \& Thomson & 0 & 0 & 0 & 0 & 0 & 0 & 0 & 0 & 1 & 0 & 1 & 1 & 0 \\
\hline 157 & $\begin{array}{l}\text { Interulobites intraverrucatus (Brenner) Phillips \& } \\
\text { Felix }\end{array}$ & 0 & 0 & 0 & 0 & 0 & 0 & 0 & 0 & 1 & 0 & 0 & 0 & 0 \\
\hline 158 & Involutisporonites crassus Song \& Cao & 0 & 0 & 0 & 0 & 0 & 0 & 0 & 0 & 0 & 0 & 1 & 0 & 0 \\
\hline 159 & Involutisporonites sp. Clarke & 0 & 0 & 0 & 0 & 0 & 0 & 0 & 0 & 0 & 0 & 1 & 0 & 0 \\
\hline
\end{tabular}




\begin{tabular}{|c|c|c|c|c|c|c|c|c|c|c|c|c|c|c|}
\hline $\mathrm{N}^{\circ}$ taxa & PALINOMORPHS & A & $\mathrm{B}$ & $\mathrm{C}$ & $\mathrm{D}$ & $\mathrm{E}$ & $\mathrm{F}$ & G & $\mathrm{H}$ & I & $\mathrm{J}$ & $\mathrm{K}$ & $\mathrm{L}$ & M \\
\hline 160 & Ischyosporites sp. Balme & 0 & 1 & 0 & 1 & 0 & 0 & 0 & 0 & 1 & 0 & 0 & 0 & 0 \\
\hline 161 & Ischyosporites volkheimeri Filatoff & 0 & 1 & 0 & 1 & 0 & 0 & 0 & 0 & 1 & 0 & 0 & 0 & 0 \\
\hline 162 & Klukisporites antarcticus $\mathrm{Cao}$ & 0 & 0 & 0 & 0 & 0 & 0 & 0 & 0 & 0 & 0 & 1 & 0 & 0 \\
\hline 163 & Klukisporites pseudoreticulatus Couper & 0 & 0 & 0 & 0 & 0 & 0 & 0 & 0 & 1 & 0 & 0 & 0 & 0 \\
\hline 164 & $\begin{array}{c}\text { Klukisporites scaberis (Cookson \& Dettmann) } \\
\text { Dettmann }\end{array}$ & 0 & 0 & 0 & 0 & 0 & 0 & 0 & 0 & 1 & 0 & 0 & 0 & 0 \\
\hline 165 & Klukisporites sp. Couper & 0 & 0 & 0 & 0 & 0 & 0 & 0 & 0 & 1 & 0 & 1 & 1 & 0 \\
\hline 167 & Lacrimasporonites scabratus Song \& Cao & 0 & 0 & 0 & 0 & 0 & 0 & 0 & 0 & 0 & 0 & 1 & 0 & 0 \\
\hline 168 & Lacrimasporonites sp. Clarke & 0 & 0 & 0 & 0 & 0 & 0 & 0 & 0 & 0 & 0 & 1 & 0 & 0 \\
\hline 169 & Lacrimasporonites tenuous Song \& Cao & 0 & 0 & 0 & 0 & 0 & 0 & 0 & 0 & 0 & 0 & 1 & 0 & 0 \\
\hline 170 & Laevigatosporites ovatus Wilson \& Webster & 0 & 1 & 0 & 1 & 1 & 0 & 0 & 1 & 1 & 0 & 0 & 0 & 0 \\
\hline 171 & Laevigatosporites sp. Tschudy \& Van Lonen & 0 & 1 & 1 & 1 & 1 & 0 & 0 & 1 & 1 & 0 & 1 & 1 & 0 \\
\hline 174 & Laurelites dorotensis Nishida & 0 & 0 & 0 & 0 & 1 & 0 & 0 & 0 & 0 & 0 & 0 & 0 & 0 \\
\hline 175 & Laurelites jamesrossii Poole \& Francis & 0 & 0 & 0 & 0 & 0 & 0 & 0 & 0 & 1 & 0 & 0 & 0 & 0 \\
\hline 179 & Leiotriletes sp. (Naumova) Potonié \& Kremp & 0 & 0 & 0 & 0 & 0 & 0 & 0 & 0 & 0 & 0 & 1 & 1 & 0 \\
\hline 180 & Leptolepidites macroverrucosus Schulz & 0 & 0 & 0 & 0 & 0 & 0 & 0 & 0 & 1 & 0 & 0 & 0 & 0 \\
\hline 181 & Leptolepidites tumulosus (Doring) Srivastava & 0 & 0 & 0 & 0 & 0 & 0 & 0 & 0 & 1 & 0 & 0 & 0 & 0 \\
\hline 182 & Leptolepidites verrucatus Couper & 0 & 0 & 0 & 0 & 0 & 0 & 0 & 0 & 1 & 0 & 0 & 0 & 0 \\
\hline 183 & Liliacidites cf. variegatus Couper & 0 & 1 & 0 & 0 & 1 & 0 & 0 & 0 & 0 & 0 & 0 & 0 & 0 \\
\hline 184 & Liliacidites kaitangataensis Couper & 0 & 0 & 0 & 1 & 0 & 0 & 0 & 1 & 1 & 0 & 0 & 0 & 0 \\
\hline 185 & Liliacidites lanceolatus Stover & 0 & 0 & 0 & 0 & 0 & 0 & 0 & 0 & 1 & 0 & 0 & 0 & 0 \\
\hline 187 & Liliacidites sp. cf. regularis Archangelsky & 0 & 1 & 1 & 1 & 0 & 0 & 0 & 1 & 1 & 0 & 1 & 1 & 0 \\
\hline 186 & Liliacidites sp. Couper & 0 & 0 & 0 & 1 & 0 & 0 & 0 & 0 & 0 & 0 & 0 & 0 & 0 \\
\hline 188 & Liliacidites variegatus Couper & 0 & 0 & 0 & 1 & 0 & 0 & 0 & 0 & 1 & 0 & 0 & 0 & 0 \\
\hline 189 & Longapertites sp. Van Hoeken-Klinkenberg & 0 & 1 & 0 & 0 & 0 & 0 & 0 & 0 & 0 & 0 & 0 & 0 & 0 \\
\hline 191 & Lycopodiumsporites sp. Danzé-Corsin y Laveine & 0 & 0 & 0 & 0 & 0 & 0 & 0 & 0 & 0 & 0 & 1 & 1 & 0 \\
\hline 193 & $\begin{array}{c}\text { Lygistepollenites florinii (Cookson y Pike) Stover \& } \\
\text { Evans }\end{array}$ & 0 & 0 & 0 & 1 & 0 & 0 & 0 & 1 & 0 & 0 & 0 & 0 & 0 \\
\hline 192 & Lygisterpollenites balmei (Cookson) Stover \& Evans 1 & 0 & 0 & 0 & 0 & 0 & 0 & 0 & 0 & 1 & 0 & 0 & 0 & 0 \\
\hline 196 & Malvacipollis sp. Harris & 0 & 0 & 0 & 0 & 0 & 0 & 0 & 0 & 0 & 0 & 1 & 1 & 0 \\
\hline 197 & Matonisporites cooksoniae Dettmann & 0 & 0 & 0 & 0 & 0 & 0 & 0 & 0 & 1 & 0 & 0 & 0 & 0 \\
\hline 198 & Matonisporites sp. Couper & 0 & 1 & 0 & 0 & 0 & 0 & 0 & 0 & 1 & 0 & 0 & 0 & 0 \\
\hline 199 & Meliapollis sp. Couper & 0 & 0 & 0 & 0 & 0 & 0 & 0 & 0 & 0 & 0 & 1 & 1 & 0 \\
\hline 202 & Microcachryidites antarcticus Cookson & 0 & 1 & 0 & 1 & 0 & 0 & 1 & 1 & 1 & 0 & 0 & 0 & 0 \\
\hline 203 & Microcachryidites sp. Cookson & 0 & 1 & 0 & 1 & 0 & 0 & 1 & 1 & 1 & 0 & 1 & 1 & 0 \\
\hline 207 & Multinodisporites praecultus Chlonova & 0 & 0 & 0 & 0 & 0 & 0 & 0 & 0 & 0 & 0 & 1 & 0 & 0 \\
\hline 208 & Multicellaesporites ovatus Sheffy \& Dilcher & 0 & 0 & 0 & 0 & 0 & 0 & 0 & 0 & 0 & 0 & 1 & 0 & 0 \\
\hline 209 & Multicellaesporites sp. (Elsik) Sheffy \& Dilcher & 0 & 0 & 0 & 0 & 0 & 0 & 0 & 0 & 0 & 0 & 1 & 1 & 0 \\
\hline 210 & Multinodisporites praecultus A. F. Chlonova & 0 & 0 & 0 & 0 & 0 & 0 & 0 & 0 & 1 & 0 & 0 & 0 & 0 \\
\hline 213 & Myrtaceidites eugeniioides Cookson \& Pike & 0 & 0 & 0 & 0 & 0 & 0 & 0 & 0 & 1 & 0 & 0 & 0 & 0 \\
\hline 214 & Myrtaceidites sp. Cookson \& Pike & 0 & 0 & 0 & 0 & 0 & 0 & 0 & 1 & 1 & 0 & 1 & 1 & 0 \\
\hline
\end{tabular}




\begin{tabular}{|c|c|c|c|c|c|c|c|c|c|c|c|c|c|c|}
\hline $\mathrm{N}^{\circ}$ taxa & PALINOMORPHS & A & $\mathrm{B}$ & $\mathrm{C}$ & $\mathrm{D}$ & $\mathrm{E}$ & $\mathrm{F}$ & $\mathrm{G}$ & $\mathrm{H}$ & I & $\mathrm{J}$ & $\mathrm{K}$ & $\mathrm{L}$ & M \\
\hline 217 & Neoraistrickia sp. Potonié & 0 & 0 & 0 & 1 & 0 & 0 & 0 & 0 & 1 & 0 & 1 & 0 & 0 \\
\hline 218 & Neoraistrickia truncata (Cookson) Potonie & 0 & 0 & 0 & 0 & 0 & 0 & 0 & 0 & 1 & 0 & 1 & 0 & 0 \\
\hline 219 & Nodosisporites cf. cremimurus (Srivastava) Davies & 0 & 0 & 0 & 0 & 0 & 0 & 0 & 0 & 1 & 0 & 0 & 0 & 0 \\
\hline 220 & Nothofagidites brachyspinulosus (Cookson) Harris & 0 & 0 & 0 & 0 & 0 & 0 & 0 & 0 & 0 & 0 & 1 & 0 & 1 \\
\hline 221 & Nothofagidites brassi Archangelsky & 0 & 0 & 0 & 0 & 0 & 0 & 0 & 0 & 0 & 0 & 1 & 1 & 0 \\
\hline 222 & $\begin{array}{c}\text { Nothofagidites cf. } N . \text { emarcidus (Cookson) Harris \& } \\
\text { Truswell }\end{array}$ & 0 & 0 & 0 & 0 & 0 & 0 & 0 & 0 & 0 & 0 & 0 & 0 & 1 \\
\hline 223 & Nothofagidites endurus Stover \& Evans & 0 & 0 & 0 & 0 & 0 & 0 & 0 & 0 & 0 & 0 & 1 & 1 & 1 \\
\hline 224 & Nothofagidites falcatus (Cookson) Hekel & 0 & 0 & 0 & 0 & 0 & 0 & 0 & 0 & 0 & 0 & 1 & 1 & 0 \\
\hline 225 & $\begin{array}{l}\text { Nothofagidites fuegiensis Menéndez \& Caccavari de } \\
\text { Fílice }\end{array}$ & 0 & 0 & 0 & 0 & 0 & 0 & 0 & 0 & 0 & 0 & 1 & 1 & 0 \\
\hline 226 & Nothofagidites fusca Cranwell Hekel & 0 & 0 & 0 & 0 & 0 & 0 & 0 & 0 & 0 & 0 & 1 & 1 & 0 \\
\hline 227 & Nothofagidites rocaensis Romero & 0 & 0 & 0 & 0 & 0 & 0 & 0 & 0 & 0 & 0 & 1 & 1 & 1 \\
\hline 228 & $\begin{array}{l}\text { Nothofagidites saraensis Menéndez \& Caccavari de } \\
\text { Fílice }\end{array}$ & 0 & 0 & 0 & 1 & 0 & 0 & 0 & 0 & 0 & 0 & 0 & 0 & 0 \\
\hline 229 & Nothofagidites senectus Dettmann \& Playford & 0 & 0 & 0 & 0 & 0 & 0 & 0 & 0 & 1 & 0 & 1 & 1 & 1 \\
\hline 230 & Nothofagidites sp. Pocknall & 0 & 0 & 0 & 0 & 0 & 0 & 1 & 1 & 1 & 0 & 1 & 1 & 1 \\
\hline 231 & Nothofagidites visserensis Romero & 0 & 0 & 0 & 0 & 0 & 0 & 0 & 0 & 0 & 0 & 1 & 1 & 0 \\
\hline 238 & Nyssapollenites cf. squamosus Dettmann & 0 & 1 & 0 & 0 & 0 & 0 & 0 & 0 & 0 & 0 & 0 & 0 & 0 \\
\hline 239 & Ornamentifera sp. Bolchovitina & 0 & 0 & 0 & 0 & 0 & 0 & 0 & 0 & 1 & 0 & 0 & 0 & 0 \\
\hline 241 & Osmundacidites sp. Couper & 0 & 0 & 0 & 0 & 0 & 0 & 0 & 0 & 1 & 0 & 1 & 1 & 0 \\
\hline 242 & Osmundacidites wellmanii Couper & 0 & 0 & 0 & 0 & 0 & 0 & 0 & 0 & 1 & 0 & 0 & 0 & 0 \\
\hline 244 & Peninsulapollis askinae Dettmann \& Jarzen & 0 & 0 & 0 & 0 & 0 & 0 & 0 & 0 & 1 & 0 & 0 & 0 & 0 \\
\hline 245 & Peninsulapollis gillii (Cookson) Dettmann \& Jarzen & 0 & 1 & 0 & 1 & 0 & 0 & 1 & 1 & 1 & 0 & 0 & 0 & 0 \\
\hline 246 & Peninsulapollis sp. Dettmann \& Jarzen & 0 & 1 & 0 & 1 & 0 & 0 & 1 & 1 & 1 & 0 & 0 & 0 & 0 \\
\hline 247 & Peninsulapollis truswelliae Dettmann \& Jarzen & 0 & 0 & 0 & 0 & 0 & 0 & 1 & 1 & 1 & 0 & 0 & 0 & 0 \\
\hline 249 & Periporopollenites sp. Pflug \& Thomson & 0 & 0 & 0 & 0 & 0 & 0 & 0 & 0 & 1 & 0 & 0 & 0 & 0 \\
\hline 250 & Perotriletes cf. P. pseudoreticulatus Couper & 0 & 0 & 0 & 0 & 0 & 0 & 1 & 0 & 1 & 0 & 0 & 0 & 0 \\
\hline 251 & Perotriletes laceratus (Norris) Rumeau & 0 & 0 & 0 & 0 & 0 & 0 & 0 & 0 & 1 & 0 & 0 & 0 & 0 \\
\hline 252 & Perotriletes linearis (Cookson \& Dettmann) Evans & 0 & 0 & 0 & 0 & 0 & 0 & 0 & 0 & 1 & 0 & 0 & 0 & 0 \\
\hline 253 & Perotriletes majus (Cookson \& Dettmann) Evans & 0 & 1 & 0 & 0 & 0 & 0 & 0 & 1 & 1 & 0 & 0 & 0 & 0 \\
\hline 254 & Phyllites sp. Brongniart & 0 & 0 & 0 & 0 & 0 & 0 & 0 & 0 & 0 & 1 & 1 & 1 & 1 \\
\hline 255 & Phyllocladidites mawsonii Cookson ex Couper & 0 & 1 & 0 & 1 & 0 & 0 & 0 & 1 & 1 & 0 & 0 & 1 & 0 \\
\hline 256 & Phyllocladidites sp.Cookson & 0 & 1 & 0 & 1 & 0 & 0 & 0 & 1 & 1 & 0 & 1 & 1 & 0 \\
\hline 260 & Plicifera decora (Chlonova) Bolchovitina & 0 & 0 & 0 & 0 & 0 & 0 & 0 & 0 & 0 & 0 & 1 & 0 & 0 \\
\hline 261 & Plicifera delicata (Bolchovitina) Bolchovitina & 0 & 0 & 0 & 0 & 0 & 0 & 0 & 0 & 0 & 0 & 1 & 0 & 0 \\
\hline 262 & Plicifera sp. Raine & 0 & 0 & 0 & 0 & 0 & 0 & 0 & 0 & 0 & 0 & 1 & 0 & 0 \\
\hline 263 & Plicifera trialatus $\mathrm{Cao}$ & 0 & 0 & 0 & 0 & 0 & 0 & 0 & 0 & 0 & 0 & 1 & 0 & 0 \\
\hline 264 & Pluricellaesporites antarcticus Song \& Cao & 0 & 0 & 0 & 0 & 0 & 0 & 0 & 0 & 0 & 0 & 1 & 0 & 0 \\
\hline 265 & Pluricellaesporites ocellatus Song \& Cao & 0 & 0 & 0 & 0 & 0 & 0 & 0 & 0 & 0 & 0 & 1 & 0 & 0 \\
\hline 266 & Pluricellaesporites sp. T. van der Hammen & 0 & 0 & 0 & 0 & 0 & 0 & 0 & 0 & 0 & 0 & 1 & 0 & 0 \\
\hline
\end{tabular}




\begin{tabular}{|c|c|c|c|c|c|c|c|c|c|c|c|c|c|c|}
\hline $\mathrm{N}^{\circ}$ taxa & PALINOMORPHS & A & $\mathrm{B}$ & $\mathrm{C}$ & $\mathrm{D}$ & $\mathrm{E}$ & $\mathrm{F}$ & G & $\mathrm{H}$ & $\mathrm{I}$ & $\mathrm{J}$ & $\mathrm{K}$ & $\mathrm{L}$ & M \\
\hline 267 & Podocarpidites elegans Romero & 0 & 1 & 0 & 1 & 0 & 0 & 0 & 0 & 0 & 0 & 0 & 0 & 0 \\
\hline 268 & Podocarpidites ellipticus Cookson & 0 & 1 & 0 & 1 & 0 & 0 & 0 & 0 & 1 & 0 & 1 & 0 & 0 \\
\hline 269 & Podocarpidites marwickii Couper & 0 & 0 & 1 & 0 & 0 & 0 & 0 & 0 & 0 & 0 & 0 & 0 & 0 \\
\hline 270 & Podocarpidites microreticuloidatus Cookson & 0 & 0 & 0 & 1 & 0 & 0 & 0 & 0 & 0 & 0 & 0 & 0 & 0 \\
\hline 271 & Podocarpidites sp. Cookson & 0 & 1 & 1 & 1 & 0 & 0 & 0 & 1 & 1 & 0 & 1 & 1 & 0 \\
\hline 275 & Podosporites microsaccatus Couper & 0 & 0 & 0 & 0 & 0 & 0 & 0 & 0 & 1 & 0 & 0 & 0 & 0 \\
\hline 276 & Podosporites sp. Rao & 0 & 0 & 0 & 0 & 0 & 0 & 0 & 1 & 0 & 0 & 0 & 0 & 0 \\
\hline 277 & Podozamites pinnatus Cantrill & 0 & 0 & 0 & 0 & 0 & 0 & 0 & 0 & 0 & 0 & 1 & 1 & 0 \\
\hline 278 & Polycolpites langstonii Stover & 0 & 0 & 0 & 0 & 0 & 0 & 0 & 1 & 1 & 0 & 0 & 0 & 0 \\
\hline 279 & Polycolpites sp. Couper \& Harris & 0 & 0 & 0 & 0 & 0 & 0 & 1 & 1 & 1 & 0 & 0 & 0 & 0 \\
\hline 280 & $\begin{array}{c}\text { Polypodiaceoisporites elegans Archangelsky \& } \\
\text { Gamerro }\end{array}$ & 0 & 0 & 0 & 0 & 0 & 0 & 0 & 0 & 1 & 0 & 0 & 0 & 0 \\
\hline 281 & Polypodiidites speciosus (Harris) Archangelsky & 0 & 0 & 0 & 1 & 0 & 0 & 0 & 0 & 0 & 0 & 0 & 0 & 0 \\
\hline 282 & Polypodiisporites favus (Potonie) Potonie & 0 & 0 & 0 & 0 & 0 & 0 & 0 & 0 & 0 & 0 & 1 & 0 & 0 \\
\hline 283 & Polypodiisporites sp. Pocknall & 0 & 0 & 0 & 0 & 0 & 0 & 0 & 0 & 1 & 0 & 1 & 0 & 0 \\
\hline 284 & Propylipollis annularis (Cookson) Martin \& Harris & 0 & 0 & 0 & 0 & 0 & 0 & 0 & 0 & 1 & 0 & 0 & 0 & 0 \\
\hline 285 & Propylipollis concretus (Harris) Martin \& Harris & 0 & 0 & 0 & 0 & 0 & 0 & 0 & 0 & 1 & 0 & 0 & 0 & 0 \\
\hline 286 & Propylipollis sp. Martin \& Harris & 0 & 0 & 0 & 0 & 0 & 0 & 0 & 1 & 1 & 0 & 1 & 1 & 0 \\
\hline 287 & Proteacidites sp. Cookson & 0 & 1 & 0 & 0 & 0 & 0 & 0 & 1 & 1 & 0 & 1 & 1 & 0 \\
\hline 288 & Proteacidites stipplatus Partridge & 0 & 0 & 0 & 0 & 0 & 0 & 0 & 0 & 1 & 0 & 0 & 0 & 0 \\
\hline 289 & Proteacidites subscabratus Couper & 0 & 0 & 0 & 0 & 0 & 0 & 0 & 0 & 1 & 0 & 0 & 0 & 0 \\
\hline 290 & Proteacidites truncatus Cookson & 0 & 0 & 0 & 0 & 0 & 0 & 0 & 0 & 1 & 0 & 0 & 0 & 0 \\
\hline 293 & $\begin{array}{l}\text { Psilatricolporites sp. T. van der Hammen ex T. van } \\
\text { der Hammen \& T. A. Wymstra }\end{array}$ & 0 & 1 & 1 & 1 & 0 & 0 & 1 & 1 & 1 & 0 & 0 & 0 & 0 \\
\hline 295 & Reduviasporonites sp. Wilson & 0 & 0 & 0 & 0 & 0 & 0 & 0 & 0 & 0 & 0 & 1 & 0 & 0 \\
\hline 296 & Reticuloidosporites cf. tenellis Krutzsch & 0 & 0 & 1 & 1 & 0 & 0 & 0 & 0 & 1 & 0 & 0 & 0 & 0 \\
\hline 297 & Retidiporites camachoi Archangelsky & 0 & 1 & 0 & 0 & 0 & 0 & 0 & 0 & 0 & 0 & 0 & 0 & 0 \\
\hline 298 & $\begin{array}{c}\text { Retistephanocolporites sp. T. van der Hammen \& } \\
\text { Wymstra }\end{array}$ & 0 & 0 & 0 & 0 & 0 & 0 & 0 & 0 & 1 & 0 & 0 & 0 & 0 \\
\hline 299 & Retitriletes austroclavatidites Cookson & 0 & 1 & 0 & 0 & 0 & 0 & 0 & 0 & 1 & 0 & 0 & 0 & 0 \\
\hline 300 & Retitriletes cf. eminulus (Dettmann) Srivastava & 0 & 0 & 0 & 0 & 0 & 0 & 0 & 0 & 1 & 0 & 0 & 0 & 0 \\
\hline 301 & Retitriletes sp. Pierce & 0 & 1 & 0 & 0 & 0 & 0 & 1 & 1 & 1 & 0 & 0 & 0 & 0 \\
\hline 302 & Rhoipites cf. minusculus Archangelsky & 0 & 1 & 1 & 0 & 0 & 0 & 0 & 0 & 0 & 0 & 0 & 0 & 0 \\
\hline 303 & $\begin{array}{l}\text { Rhoipites sp. cf. microreticulatus (Harris) Macphail } \\
\text { et al. }\end{array}$ & 0 & 1 & 1 & 0 & 0 & 0 & 0 & 1 & 0 & 0 & 0 & 0 & 0 \\
\hline 304 & Rhoipites sp. Wodehouse & 0 & 0 & 0 & 0 & 0 & 0 & 0 & 1 & 0 & 0 & 0 & 0 & 0 \\
\hline 305 & Rousea microreticulata Archangelsky & 0 & 0 & 0 & 1 & 0 & 0 & 0 & 0 & 0 & 0 & 0 & 0 & 0 \\
\hline 306 & Rousea patagonica Archangelsky & 0 & 1 & 0 & 0 & 0 & 0 & 0 & 0 & 0 & 0 & 0 & 0 & 0 \\
\hline 307 & Rousea sp. Srivastava & 0 & 0 & 0 & 1 & 0 & 0 & 0 & 0 & 1 & 0 & 0 & 0 & 0 \\
\hline 308 & Rouseisporites reticulatus Pocock & 0 & 1 & 0 & 0 & 0 & 0 & 0 & 1 & 0 & 0 & 0 & 0 & 0 \\
\hline 309 & Rugulatisporites mallatus Stover & 0 & 0 & 0 & 0 & 0 & 0 & 0 & 0 & 1 & 0 & 0 & 0 & 0 \\
\hline
\end{tabular}




\begin{tabular}{|c|c|c|c|c|c|c|c|c|c|c|c|c|c|c|}
\hline $\mathrm{N}^{\circ}$ taxa & PALINOMORPHS & A & B & $\mathrm{C}$ & $\mathrm{D}$ & $\mathrm{E}$ & $\mathrm{F}$ & G & $\mathrm{H}$ & I & $\mathrm{J}$ & $\mathrm{K}$ & $\mathrm{L}$ & M \\
\hline 310 & Rugulatisporites micraulaxus Partridge & 0 & 0 & 0 & 0 & 0 & 0 & 0 & 0 & 1 & 0 & 0 & 0 & 0 \\
\hline 311 & Rugulatisporites neuquensis Volkheimer & 0 & 0 & 0 & 0 & 0 & 0 & 0 & 0 & 1 & 0 & 0 & 0 & 0 \\
\hline 312 & Sapotacoidaepollenites sp. Stover & 0 & 0 & 0 & 0 & 0 & 0 & 0 & 0 & 0 & 0 & 1 & 1 & 0 \\
\hline 313 & Schizocolpus sp. Stover & 0 & 0 & 0 & 0 & 0 & 0 & 0 & 0 & 0 & 0 & 1 & 1 & 0 \\
\hline 314 & Senipites sp. Srivastava & 0 & 1 & 0 & 0 & 0 & 0 & 0 & 0 & 0 & 0 & 0 & 0 & 0 \\
\hline 316 & Sphagnumsporites sp. Cookson & 0 & 0 & 0 & 0 & 0 & 0 & 0 & 0 & 0 & 0 & 1 & 0 & 0 \\
\hline 318 & Spinizonocolpites hialinus Zamaloa \& Archangelsky & 0 & 1 & 0 & 0 & 0 & 0 & 0 & 0 & 0 & 0 & 0 & 0 & 0 \\
\hline 319 & Staphlosporonites sp. Sheffy \& Dilcher & 0 & 0 & 0 & 0 & 0 & 0 & 0 & 0 & 0 & 0 & 1 & 0 & 0 \\
\hline 320 & Stellidiopollis annulatus Dettmann \& Hedlund & 0 & 0 & 0 & 0 & 0 & 0 & 0 & 1 & 1 & 0 & 0 & 0 & 0 \\
\hline 321 & Stephanocolpites sp. T. van der Hammen & 0 & 0 & 0 & 0 & 0 & 0 & 0 & 0 & 1 & 0 & 0 & 0 & 0 \\
\hline 327 & $\begin{array}{c}\text { Stereisporites antiquasporites (Wilson \& Webster) } \\
\text { Dettmann }\end{array}$ & 0 & 1 & 0 & 1 & 0 & 0 & 0 & 1 & 0 & 0 & 0 & 0 & 0 \\
\hline 328 & Stereisporites sp. Norris & 0 & 0 & 0 & 0 & 0 & 0 & 0 & 1 & 0 & 0 & 1 & 1 & 0 \\
\hline 329 & Stoverisporites microverrucatus Burger & 0 & 0 & 0 & 0 & 0 & 0 & 0 & 0 & 1 & 0 & 0 & 0 & 0 \\
\hline 330 & Striatriporites sp. van Hoeken-Klinkenberg & 0 & 0 & 0 & 0 & 0 & 0 & 0 & 0 & 1 & 0 & 0 & 0 & 0 \\
\hline 332 & Teredolites sp. Savrda & 0 & 0 & 0 & 0 & 0 & 0 & 1 & 0 & 0 & 0 & 0 & 0 & 0 \\
\hline 333 & Tetracolporites sp. Couper & 0 & 0 & 0 & 0 & 0 & 0 & 0 & 1 & 1 & 0 & 0 & 0 & 0 \\
\hline 334 & Tetracolporites verrucosus Stover & 0 & 0 & 0 & 0 & 0 & 0 & 0 & 1 & 0 & 0 & 0 & 0 & 0 \\
\hline 339 & Triatriopollenites lateflexus Archangelsky & 0 & 0 & 0 & 1 & 0 & 0 & 0 & 0 & 0 & 0 & 0 & 0 & 0 \\
\hline 340 & Trichotomosulcites subgranulatus Couper & 0 & 0 & 0 & 0 & 0 & 0 & 0 & 1 & 0 & 0 & 0 & 0 & 0 \\
\hline 341 & Tricolpites confessus Stover ex Stover \& Partridge & 0 & 0 & 0 & 0 & 0 & 0 & 0 & 0 & 1 & 0 & 0 & 0 & 0 \\
\hline 342 & Tricolpites reticulatus Cookson & 0 & 0 & 0 & 1 & 0 & 0 & 0 & 1 & 1 & 0 & 0 & 0 & 0 \\
\hline 343 & Tricolpites simatus Stover \& Partridge & 0 & 0 & 0 & 0 & 0 & 0 & 0 & 0 & 1 & 0 & 0 & 0 & 0 \\
\hline 344 & Tricolpites sp. T. van der Hammen & 0 & 0 & 1 & 1 & 0 & 0 & 0 & 1 & 1 & 0 & 1 & 1 & 0 \\
\hline 345 & Tricolpites striatus Couper & 0 & 0 & 0 & 0 & 0 & 0 & 0 & 1 & 0 & 0 & 0 & 0 & 0 \\
\hline 346 & Tricolpites waiparaensis Stover \& Evans & 0 & 0 & 0 & 0 & 0 & 0 & 0 & 0 & 1 & 0 & 0 & 0 & 0 \\
\hline 347 & Tricolporites lilliei (Couper) Stover \& Evans & 0 & 0 & 0 & 0 & 0 & 0 & 0 & 0 & 0 & 0 & 0 & 1 & 0 \\
\hline 348 & Tricolporites pachyexinus Couper & 0 & 0 & 0 & 0 & 0 & 0 & 0 & 1 & 0 & 0 & 0 & 0 & 0 \\
\hline 349 & Tricolporopollenites sp. Doyle \& Robbins & 0 & 0 & 0 & 0 & 0 & 0 & 0 & 0 & 0 & 0 & 1 & 0 & 0 \\
\hline 350 & Trilites parvallatus Krutzsch & 0 & 0 & 0 & 0 & 0 & 0 & 0 & 0 & 1 & 0 & 0 & 0 & 0 \\
\hline 351 & Trilites sp. Mildenhall & 0 & 0 & 0 & 1 & 0 & 0 & 0 & 0 & 1 & 0 & 0 & 0 & 0 \\
\hline 352 & Trilites sp. cf. fasolae Archangelsky & 0 & 0 & 0 & 1 & 0 & 0 & 0 & 0 & 0 & 0 & 0 & 0 & 0 \\
\hline 353 & Trilites tuberculiformis Cookson & 0 & 0 & 0 & 0 & 0 & 0 & 0 & 0 & 1 & 0 & 0 & 0 & 0 \\
\hline 354 & Triorites sp. Erdtman & 0 & 0 & 0 & 0 & 0 & 0 & 0 & 0 & 0 & 0 & 1 & 1 & 0 \\
\hline 355 & Triporoletes simplex (Cookson \& Dettmann) Playford & 0 & 0 & 0 & 0 & 0 & 0 & 0 & 0 & 1 & 0 & 0 & 0 & 0 \\
\hline 356 & Triporopollenites sectilis Stover & 0 & 0 & 0 & 0 & 0 & 0 & 0 & 1 & 0 & 0 & 0 & 0 & 0 \\
\hline 357 & Triporopollenites sp. Pflug \& Thomson & 0 & 0 & 0 & 1 & 0 & 0 & 0 & 1 & 1 & 0 & 1 & 0 & 0 \\
\hline 358 & Trisaccites microsaccatus Couper & 0 & 1 & 1 & 0 & 1 & 0 & 0 & 1 & 0 & 0 & 0 & 0 & 0 \\
\hline 359 & Tuberculatosporites parvus Archangelsky & 0 & 0 & 0 & 0 & 0 & 0 & 0 & 0 & 1 & 0 & 0 & 0 & 0 \\
\hline 360 & Tubulifloridites lilliei Couper & 0 & 0 & 0 & 0 & 0 & 0 & 0 & 1 & 1 & 0 & 0 & 0 & 0 \\
\hline 361 & Undulatisporites sp. Pflug & 0 & 0 & 0 & 0 & 0 & 0 & 0 & 0 & 0 & 0 & 1 & 0 & 0 \\
\hline
\end{tabular}




\begin{tabular}{lcccccccccccccc}
\hline $\mathrm{N}^{\circ}$ taxa & PALINOMORPHS & A & B & C & D & E & F & G & H & I & J & K & L & M \\
\hline 362 & Verrucosisporites sp. Dybová \& Jachowicz & 0 & 1 & 1 & 1 & 0 & 0 & 0 & 0 & 0 & 0 & 1 & 1 & 0 \\
363 & Vitreisporites pallidus Reissinger & 0 & 0 & 0 & 0 & 0 & 0 & 0 & 0 & 1 & 0 & 0 & 0 & 0 \\
\hline
\end{tabular}

\begin{tabular}{|c|c|c|c|c|c|c|c|c|c|c|c|c|c|c|}
\hline $\mathrm{N}^{\circ}$ taxa & LEAF IMPRINTS & A & B & $\mathrm{C}$ & $\mathrm{D}$ & $\mathrm{E}$ & $\mathrm{F}$ & G & $\mathrm{H}$ & I & $\mathrm{J}$ & $\mathrm{K}$ & $\mathrm{L}$ & M \\
\hline 1 & Acmopyle antarctica Florin & 0 & 0 & 0 & 0 & 0 & 1 & 0 & 0 & 0 & 0 & 0 & 0 & 0 \\
\hline 11 & Araliaephyllum sp. Fontaine & 0 & 0 & 0 & 0 & 0 & 1 & 0 & 0 & 0 & 0 & 0 & 0 & 1 \\
\hline 18 & Athrotaxis sp. Don & 0 & 0 & 1 & 0 & 0 & 0 & 0 & 0 & 0 & 0 & 0 & 0 & 0 \\
\hline 29 & Blechnum sp. Linneo & 0 & 0 & 0 & 0 & 0 & 0 & 0 & 0 & 0 & 0 & 1 & 1 & 0 \\
\hline 39 & Carpolithes sp. Brongniart & 0 & 0 & 1 & 0 & 0 & 0 & 0 & 0 & 0 & 0 & 0 & 0 & 0 \\
\hline 40 & Cassia sp. Linnaeus & 0 & 0 & 0 & 0 & 0 & 0 & 0 & 0 & 0 & 1 & 1 & 0 & 0 \\
\hline 49 & Cinnamonum sp. Schaeff. & 0 & 0 & 1 & 0 & 0 & 1 & 0 & 0 & 0 & 0 & 0 & 0 & 0 \\
\hline 50 & Cissites parrifolius Cockerell & 0 & 0 & 1 & 0 & 0 & 0 & 0 & 0 & 0 & 0 & 0 & 0 & 0 \\
\hline 51 & Cladophlebis patagonica (Frenguelli) Herbst & 0 & 0 & 1 & 0 & 0 & 0 & 0 & 0 & 0 & 0 & 0 & 0 & 0 \\
\hline 52 & Cladophlebis sp. Brongniart & 0 & 0 & 1 & 0 & 0 & 1 & 0 & 0 & 0 & 0 & 1 & 1 & 1 \\
\hline 68 & Culcita sp. Presl & 0 & 0 & 0 & 0 & 0 & 0 & 0 & 0 & 0 & 1 & 1 & 0 & 0 \\
\hline 69 & Cupania patagonica Berry & 0 & 0 & 1 & 0 & 0 & 0 & 0 & 0 & 0 & 0 & 0 & 0 & 0 \\
\hline 96 & Dicksonia sp. L'Héritier & 0 & 0 & 0 & 0 & 0 & 0 & 0 & 0 & 0 & 0 & 1 & 1 & 0 \\
\hline 97 & Dicotylophyllum elegans Li & 0 & 0 & 0 & 0 & 0 & 0 & 0 & 0 & 0 & 1 & 1 & 0 & 1 \\
\hline 98 & Dicotylophyllum sp. Bandulska & 0 & 0 & 0 & 0 & 0 & 0 & 0 & 0 & 0 & 1 & 1 & 0 & 1 \\
\hline 102 & Dryopteris seymouriensis Dusen & 0 & 0 & 0 & 0 & 0 & 0 & 0 & 0 & 0 & 0 & 0 & 0 & 1 \\
\hline 103 & Dryopteris sp. Adanson & 0 & 0 & 0 & 0 & 0 & 0 & 0 & 0 & 0 & 0 & 1 & 1 & 1 \\
\hline 108 & Elaeocarpus sp. Linnaeus & 0 & 0 & 0 & 0 & 0 & 0 & 0 & 0 & 0 & 0 & 0 & 0 & 1 \\
\hline 109 & Ephedra notensis Linnaeus & 0 & 0 & 0 & 0 & 0 & 0 & 0 & 1 & 0 & 0 & 0 & 0 & 0 \\
\hline 111 & Equisetites sp. Sternberg & 0 & 0 & 1 & 0 & 0 & 0 & 0 & 0 & 0 & 0 & 0 & 0 & 0 \\
\hline 117 & Ficophyllum palustris Cantrill & 0 & 0 & 0 & 0 & 0 & 0 & 0 & 0 & 0 & 1 & 1 & 0 & 0 \\
\hline 118 & Ficophyllum skuaensis Dutra & 0 & 0 & 0 & 0 & 0 & 0 & 0 & 0 & 0 & 1 & 0 & 0 & 0 \\
\hline 131 & Garnbierina rudata Stover & 0 & 0 & 0 & 0 & 0 & 0 & 0 & 1 & 0 & 0 & 0 & 0 & 0 \\
\hline 133 & Gleichenia sp. Smith & 0 & 0 & 0 & 0 & 0 & 1 & 0 & 0 & 0 & 0 & 1 & 1 & 0 \\
\hline 151 & Hymenophyllum priscum Menéndez & 0 & 0 & 0 & 0 & 0 & 1 & 0 & 0 & 0 & 0 & 0 & 0 & 0 \\
\hline 166 & Knightia andreae Dusen & 0 & 0 & 0 & 0 & 0 & 0 & 0 & 0 & 0 & 0 & 0 & 0 & 1 \\
\hline 176 & Laurophyllum hickenii Mendéndez & 0 & 0 & 1 & 0 & 0 & 0 & 0 & 0 & 0 & 0 & 0 & 0 & 0 \\
\hline 177 & Laurophyllum proteaefolium Berry ex Menendez & 0 & 0 & 1 & 0 & 0 & 1 & 0 & 0 & 0 & 0 & 0 & 0 & 0 \\
\hline 178 & Laurophyllum sp. Kartzi Berry & 0 & 0 & 1 & 0 & 0 & 1 & 0 & 0 & 0 & 0 & 0 & 0 & 0 \\
\hline 190 & Lophozonia sp. Turczaninow & 0 & 0 & 0 & 0 & 0 & 0 & 0 & 0 & 1 & 0 & 0 & 0 & 0 \\
\hline 194 & Lygodium sp. Swartz & 0 & 0 & 0 & 0 & 0 & 1 & 0 & 0 & 0 & 0 & 0 & 0 & 0 \\
\hline 195 & Magnoliidaephyllum birkenmajeri Zastawniak & 0 & 0 & 0 & 0 & 0 & 0 & 0 & 0 & 0 & 0 & 0 & 0 & 1 \\
\hline 199 & Menispermites sp. Lesquereux & 0 & 0 & 1 & 0 & 0 & 1 & 0 & 0 & 0 & 0 & 0 & 0 & 0 \\
\hline 201 & Mespilodaphne longifolia Meisn & 0 & 0 & 0 & 0 & 0 & 0 & 0 & 0 & 0 & 0 & 0 & 0 & 1 \\
\hline 204 & Microcachrys sp. Hooker & 0 & 0 & 0 & 0 & 0 & 0 & 0 & 1 & 0 & 0 & 0 & 0 & 0 \\
\hline
\end{tabular}




\begin{tabular}{|c|c|c|c|c|c|c|c|c|c|c|c|c|c|c|}
\hline $\mathrm{N}^{\circ}$ taxa & LEAF IMPRINTS & A & $\mathrm{B}$ & $\mathrm{C}$ & $\mathrm{D}$ & $\mathrm{E}$ & $\mathrm{F}$ & G & $\mathrm{H}$ & $\mathrm{I}$ & $\mathrm{J}$ & $\mathrm{K}$ & $\mathrm{L}$ & M \\
\hline 205 & Monimiophyllum antarcticum Zastawniak & 0 & 0 & 0 & 0 & 0 & 0 & 0 & 0 & 0 & 1 & 1 & 0 & 1 \\
\hline 206 & Monimiophyllum sp. Zastawniak & 0 & 0 & 0 & 0 & 0 & 0 & 0 & 0 & 0 & 1 & 1 & 0 & 1 \\
\hline 211 & Myrcia chubutensis Berry & 0 & 0 & 1 & 0 & 0 & 0 & 0 & 0 & 0 & 0 & 0 & 0 & 0 \\
\hline 212 & Myrciophyllum santacruzensis (Berry) Zastawniak & 0 & 0 & 1 & 0 & 0 & 0 & 0 & 0 & 0 & 0 & 0 & 0 & 1 \\
\hline 215 & Myrtoidea patagonica Passalía et al. & 0 & 0 & 1 & 0 & 0 & 0 & 0 & 0 & 0 & 0 & 0 & 0 & 0 \\
\hline 216 & Nelumbo sp. Adanson & 0 & 0 & 1 & 0 & 0 & 0 & 0 & 0 & 0 & 0 & 0 & 0 & 0 \\
\hline 232 & Nothofagus cretacea Zastawniak & 0 & 0 & 0 & 0 & 0 & 0 & 0 & 0 & 0 & 0 & 1 & 1 & 1 \\
\hline 233 & Nothofagus glaucifolia Dutra & 0 & 0 & 0 & 0 & 0 & 0 & 0 & 0 & 0 & 0 & 0 & 0 & 1 \\
\hline 234 & Nothofagus sp. Tshudy \& Van Loenen & 0 & 0 & 0 & 0 & 0 & 1 & 0 & 1 & 1 & 1 & 1 & 1 & 1 \\
\hline 235 & $\begin{array}{l}\text { Nothofagus sp. aff. lendenfeldii (Ettingshausen) } \\
\text { Oliver }\end{array}$ & 0 & 0 & 0 & 0 & 0 & 0 & 0 & 0 & 0 & 0 & 0 & 0 & 1 \\
\hline 236 & Nothofagus sp. aff. ulmifolia (Ettingshausen) Oliver & 0 & 0 & 0 & 0 & 0 & 0 & 0 & 0 & 0 & 0 & 0 & 0 & 1 \\
\hline 237 & Nothofagus zastawniakiae Dutra & 0 & 0 & 0 & 0 & 0 & 0 & 0 & 0 & 0 & 0 & 0 & 0 & 1 \\
\hline 240 & Osmunda sp. Linnaeus & 0 & 0 & 0 & 0 & 0 & 0 & 0 & 0 & 0 & 1 & 1 & 0 & 0 \\
\hline 243 & Pecopteris sp. Sternberg & 0 & 0 & 0 & 0 & 0 & 0 & 0 & 0 & 0 & 0 & 0 & 0 & 1 \\
\hline 248 & Pentaneurum dusenii (Zastawniak) Li & 0 & 0 & 0 & 0 & 0 & 0 & 0 & 0 & 0 & 0 & 0 & 0 & 1 \\
\hline 257 & $\begin{array}{c}\text { Phyllocladus aspleniifolius (Labillardière) J. D. } \\
\text { Hooker }\end{array}$ & 0 & 0 & 0 & 0 & 0 & 0 & 0 & 0 & 0 & 1 & 1 & 0 & 0 \\
\hline 258 & Phyllocladus sp. Mirbel & 0 & 0 & 1 & 0 & 0 & 0 & 0 & 0 & 0 & 1 & 1 & 1 & 0 \\
\hline 259 & Phyllopteroides leavis Cantrill \& Webb & 0 & 0 & 1 & 0 & 0 & 0 & 0 & 0 & 0 & 0 & 0 & 0 & 0 \\
\hline 272 & Podocarpus fildesensis Zhou & 0 & 0 & 0 & 0 & 0 & 0 & 0 & 0 & 0 & 0 & 1 & 0 & 0 \\
\hline 273 & Podocarpus inopinatus Florin & 0 & 0 & 1 & 0 & 0 & 1 & 0 & 0 & 0 & 0 & 0 & 0 & 0 \\
\hline 274 & Podocarpus sp. Persoon & 0 & 0 & 0 & 0 & 0 & 1 & 0 & 1 & 0 & 1 & 1 & 1 & 1 \\
\hline 291 & Pseudoaraucaria valentini Lamberti & 0 & 0 & 0 & 0 & 0 & 1 & 0 & 0 & 0 & 0 & 0 & 0 & 0 \\
\hline 292 & Pseudopanax sp. Vargas & 0 & 0 & 1 & 0 & 0 & 0 & 0 & 0 & 0 & 0 & 0 & 0 & 0 \\
\hline 294 & Quadraplanus brossus (Stover) Stover \& Partridge & 0 & 0 & 0 & 0 & 0 & 0 & 0 & 1 & 0 & 0 & 0 & 0 & 0 \\
\hline 315 & Sloanea sp. Linnaeus & 0 & 0 & 0 & 0 & 0 & 0 & 0 & 0 & 0 & 0 & 0 & 0 & 1 \\
\hline 317 & Sphenopteris sp. (Brongniart) Sternberg & 0 & 0 & 1 & 0 & 0 & 0 & 0 & 0 & 0 & 0 & 1 & 0 & 0 \\
\hline 322 & Sterculia acuminataloba Berry & 0 & 0 & 1 & 0 & 0 & 0 & 0 & 0 & 0 & 0 & 0 & 0 & 0 \\
\hline 323 & Sterculia cretaceum (Velenovsky) Berry & 0 & 0 & 0 & 0 & 0 & 1 & 0 & 0 & 0 & 0 & 0 & 0 & 0 \\
\hline 324 & Sterculia sehuensis Berry & 0 & 0 & 1 & 0 & 0 & 1 & 0 & 0 & 0 & 0 & 0 & 0 & 0 \\
\hline 325 & Sterculia washburnii Berry & 0 & 0 & 0 & 0 & 0 & 0 & 0 & 0 & 0 & 1 & 1 & 0 & 1 \\
\hline 326 & Sterculiaephyllum australis Dutra & 0 & 0 & 1 & 0 & 0 & 0 & 0 & 0 & 0 & 1 & 1 & 0 & 1 \\
\hline 331 & Taeniopteris sp. Brongniart & 0 & 0 & 1 & 0 & 0 & 1 & 0 & 0 & 0 & 0 & 0 & 0 & 0 \\
\hline 335 & Thorhallenia sp. Passalia & 0 & 0 & 1 & 0 & 0 & 0 & 0 & 0 & 0 & 0 & 0 & 0 & 0 \\
\hline 336 & Thyrsopteris antiqua Menendez & 0 & 0 & 0 & 0 & 1 & 1 & 0 & 0 & 0 & 0 & 0 & 0 & 0 \\
\hline 337 & Thyrsopteris elegans Kunze & 0 & 0 & 0 & 0 & 0 & 0 & 0 & 0 & 0 & 1 & 1 & 0 & 0 \\
\hline 338 & Thyrsopteris sp. Wilson & 0 & 0 & 0 & 0 & 1 & 1 & 0 & 0 & 1 & 1 & 1 & 0 & 0 \\
\hline
\end{tabular}

